ARTICLE

\title{
Unique structure of active platinum-bismuth site for oxidation of carbon monoxide
}

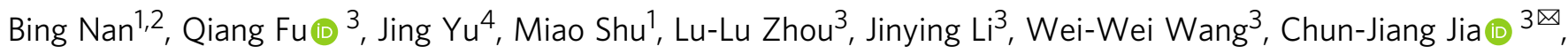
Chao Ma ${ }^{5 凶}$, Jun-Xiang Chen ${ }^{6}$, Lina $\mathrm{Li}^{1,7} \&$ Rui Si ${ }^{1,7}{ }^{1,7}$

As the technology development, the future advanced combustion engines must be designed to perform at a low temperature. Thus, it is a great challenge to synthesize high active and stable catalysts to resolve exhaust below $100^{\circ} \mathrm{C}$. Here, we report that bismuth as a dopant is added to form platinum-bismuth cluster on silica for $\mathrm{CO}$ oxidation. The highly reducible oxygen species provided by surface metal-oxide (M-O) interface could be activated by $\mathrm{CO}$ at low temperature $\left(\sim 50^{\circ} \mathrm{C}\right)$ with a high $\mathrm{CO}_{2}$ production rate of $487 \mu \mathrm{mol} \mathrm{CO}_{2} \cdot \mathrm{gPt}^{-1} \cdot \mathrm{s}^{-1}$ at $110^{\circ} \mathrm{C}$. Experiment data combined with density functional calculation (DFT) results demonstrate that Pt cluster with surface $\mathrm{Pt}-\mathrm{O}-\mathrm{Bi}$ structure is the active site for $\mathrm{CO}$ oxidation via providing moderate $\mathrm{CO}$ adsorption and activating $\mathrm{CO}$ molecules with electron transformation between platinum atom and carbon monoxide. These findings provide a unique and general approach towards design of potential excellent performance catalysts for redox reaction.

\footnotetext{
${ }^{1}$ Shanghai Institute of Applied Physics, Chinese Academy of Sciences, Shanghai, China. ${ }^{2}$ University of Chinese Academy of Science, Beijing, China. ${ }^{3}$ Key Laboratory for Colloid and Interface Chemistry, Key Laboratory of Special Aggregated Materials, School of Chemistry and Chemical Engineering, Shandong University, Jinan, China. ${ }^{4}$ Shanghai Institute of Measurement and Testing Technology, Shanghai, China. ${ }^{5}$ Center for High Resolution Electron Microscopy, College of Materials Science and Engineering, Hunan University, Changsha, China. ${ }^{6}$ Division of China, TILON Group Technology Limited, Shanghai, China. ${ }^{7}$ Shanghai Synchrotron Radiation Facility, Zhangjiang Laboratory, Shanghai Advanced Research Institute, Shanghai, China. ${ }^{凶}$ email: jiacj@sdu.edu.cn; cma@hnu.edu.cn; sirui@sinap.ac.cn
} 
T he $\mathrm{CO}$ oxidation reaction $\left(\mathrm{CO}+1 / 2 \mathrm{O}_{2}=\mathrm{CO}_{2}\right)$ is a wellknown model reaction in heterogeneous catalysis, as well as a key step to resolve automobile exhaust containing $\mathrm{CO}$, $\mathrm{NO}$, and hydrocarbons $\mathrm{s}^{1-5}$. According to the previous reports, the platinum (Pt)-based catalysts exhibit excellent catalytic activity in $\mathrm{CO}$ oxidation. In one hand, these high-performance catalysts always require reducible oxides as supports, such as $\mathrm{CeO}_{2}{ }^{2}$, $\mathrm{FeO}_{x}^{3}, \mathrm{MnO}_{2}^{4}$, and $\mathrm{Co}_{3} \mathrm{O}_{4}^{4}$, due to their rich surface oxygen vacancy and the so-called "strong metal-support interaction" $6-8$. In another hand, the irreducible oxide $\left(\mathrm{SiO}_{2}\right.$ and $\left.\mathrm{Al}_{2} \mathrm{O}_{3}\right)$-supported platinum catalysts with the advantages of commercial production, low cost, and extensive application frequently show poor catalytic activity in $\mathrm{CO}$ oxidation especially in low temperature because of the lack of surface activated oxygen and suitable active site $e^{9,10}$. Meanwhile, the aggregation of platinum species in $\mathrm{SiO}_{2}$-supported platinum catalysts frequently results in the deactivation of catalysts in $\mathrm{CO}$ oxidation. Therefore, it is a big challenge to develop a kind of irreducible oxide-supported platinum catalyst with both excellent catalytic performance in low temperature and thermo-stability for practical application.

Many research groups have found that the addition of a secondary element, such as $\mathrm{Sn}^{5}, \mathrm{~K}^{11}, \mathrm{Co}^{12}$, and $\mathrm{Bi}^{13,14}$, distinctly improved the activity of silica- or alumina-supported platinum catalysts, no matter in the form of oxide clusters or metallic alloy for Pt. As for bismuth element, it has been widely used as the secondary element to improve the catalytic activity in various oxidative reactions ${ }^{13,14}$, due to providing high content of mobile oxygen $^{13}$, preventing the overoxidation of noble metal ${ }^{15}$ and suppressing adsorption of poisoning species ${ }^{16}$. Many research groups have prepared crystalline platinum-bismuth alloy to promote the activity of some oxidation reactions. However, bismuth as an oxyphilic element is easily to form $\mathrm{Bi}^{3+}$ species in oxidative atmosphere resulting in oxidation of platinum-bismuth alloy. Feng et al. ${ }^{17}$ reported that the metallic and positive bismuth species coexists in Pt-Bi/SBA-15 catalysts for the selective oxidation of glycerol. In addition, the deposit location of bismuth species (on the surface of support or active site) also have huge influence on catalytic performance ${ }^{17,18}$. Therefore, it is significant for us to determine the precise local structure of active site (alloy or oxide cluster? ${ }^{14}$ ) and the practical valance state of bismuth and platinum (metallic or positive charge? ${ }^{19,20}$ ) for Bi-promoted platinum catalysts in oxidation reactions. In this work, we provide a special viewpoint of active site: partially oxidized $\mathrm{Pt}-[\mathrm{O}]_{x}-\mathrm{Bi}$ structure totally different with PtBi alloy to improve the thermostability of catalysts and supply active oxygen species for efficiently catalyzing $\mathrm{CO}$ oxidation at low temperature.

Moreover, many researchers have identified that various interfaces in platinum-based catalysts play a key role in many industrially important reactions, such as metal-support ${ }^{3,21,22}$, metal-oxide ${ }^{23-25}$ and metal-metal hydroxide ${ }^{26}$. Chen et al. reported iron nickel hydroxide-platinum nanoparticles $(\mathrm{Pt}-\mathrm{OH}-\mathrm{Fe} / \mathrm{Ni})$ were highly efficient for $\mathrm{CO}$ oxidation owing to abundant sites of Pt-OH-M interfaces ${ }^{26}$. According to previous reports ${ }^{27,28}$, it is easy to build multifarious atomic interface between metal and reducible oxide to improve catalytic performance. However, it is quite difficult to build effective metalsupport or metal-oxide interface due to the infertile oxygen, poor reducibility and over-stable surface composition of irreducible oxide $\left(\mathrm{SiO}_{2}\right.$ and $\left.\mathrm{Al}_{2} \mathrm{O}_{3}\right)$. Therefore, it is great research interests to build stable and efficient interfaces via the doping of secondary element on inert support to improve the catalytic performance in $\mathrm{CO}$ oxidation.

In this work, we prepared silica-supported platinum-bismuth catalysts via an incipient wetness impregnation, possessing excellent sinter resistance due to the formation of oxidized
$\mathrm{Pt}_{x} \mathrm{Bi}_{y} \mathrm{O}_{z}$ cluster. The dopant of bismuth species builds a unique interface between platinum and bismuth $\left(\mathrm{Pt}-[\mathrm{O}]_{x}-\mathrm{Bi}\right.$ structure) species, which exhibits an absolutely different active site compared with pure platinum sample, providing superior active oxygen species activated by $\mathrm{CO}$ at low temperature $\left(\sim 50^{\circ} \mathrm{C}\right)$ with a high $\mathrm{CO}_{2}$ production rate of $487 \mu \mathrm{mol}_{\mathrm{CO} 2} \mathrm{~g}_{\mathrm{Pt}}{ }^{-1} \mathrm{~s}^{-1}$ at $110^{\circ} \mathrm{C}$. Meanwhile, this interface structure prevents oversaturated $\mathrm{CO}$ adsorption from poison of platinum species and activates $\mathrm{CO}$ molecules to catalyze $\mathrm{CO}$ oxidation in a lower apparent activation energy.

\section{Results}

Structural characterization of bismuth-doped platinum samples. A serial of silica-supported platinum and platinum-bismuth samples were prepared by a co-incipient wetness impregnation method. The bulk concentrations of platinum and bismuth (Pt: $0.8,0.9$, and 0.9 wt.\%; Bi: 2.3 , and 6.1 wt.\% for $1 \mathrm{Pt}-\mathrm{SiO}_{2}$, $1 \mathrm{Pt} 2 \mathrm{Bi}-\mathrm{SiO}_{2}, \quad 1 \mathrm{Pt} 5 \mathrm{Bi}-\mathrm{SiO}_{2}$ respectively) are close to these designed numbers, indicating the disposition of bismuth species have no effect on the loading of platinum (Supplementary Table 1). Furthermore, the Bi-free and Bi-doped samples have similar textural properties, such as $S_{\mathrm{BET}}$ values and the type of adsorption-desorption isotherms (Supplementary Table 1 and Supplementary Fig. 1), in which we can exclude the physical effect on the following catalytic performance.

Small-size oxide species were quite stable on silica surface in Bi-promoted samples in aberration-corrected high-angle annular dark-field imaging scanning transmission electron microscopy (HAADF-STEM) images (Fig. 1a, b), even after heat treatment in air. Only ultrafine clusters of $1.7 \pm 0.4 \mathrm{~nm}$ with narrow sizedistribution were created in $1 \mathrm{Pt} 2 \mathrm{Bi}-\mathrm{SiO}_{2}$ (Supplementary Fig. 2e, $\mathrm{f}$ and 3a), without any crystallized platinum or bismuth metal/ oxide particles. However, after calcination in air, huge metallic $\mathrm{Pt}$ particles of $\sim 100 \mathrm{~nm}$ (Supplementary Fig. 2a) and platinum oxide clusters $(1.6 \pm 0.5 \mathrm{~nm})$ simultaneously appeared in $1 \mathrm{Pt}-\mathrm{SiO}_{2}$ (Supplementary Fig. 2b, c and 3b). It illustrates that the addition of bismuth element could suppress the growth of metal/oxide particles, similar to the promotion by alkali ions ${ }^{11}$ and silica support shows poor ability to stabilize platinum species. Furthermore, the corresponding aberration-corrected energy dispersive spectroscopy (EDS) mapping results of $1 \mathrm{Pt} 2 \mathrm{Bi}-\mathrm{SiO}_{2}$ (Fig. 1c) show that platinum and bismuth elements distribute uniformly at the cluster level within the same areas on the surface of $\mathrm{SiO}_{2}$ without evident separation. When the EDS mapping was conducted for the individual cluster, no obvious core-shell structure can be observed (Supplementary Fig. 3c). Xie et al. also reported that bismuth species was deposited selectively on the Pt particles rather than carbon support ${ }^{29}$. Meanwhile, the X-ray diffraction (XRD) also confirmed the promotion of bismuth species, in which no obvious $\mathrm{Pt} / \mathrm{PtO} / \mathrm{PtO}_{2} / \mathrm{Bi} / \mathrm{Bi}_{2} \mathrm{O}_{3}$ phase was detected in $1 \mathrm{Pt} 2 \mathrm{Bi}-\mathrm{SiO}_{2}$, even in a "slow-scan" mode (Fig. 1d and Supplementary Fig. 4). When bismuth oxide species were deposited on silica separately $\left(2 \mathrm{Bi}-\mathrm{SiO}_{2}\right)$, it also stabilized in small-size without any diffraction peaks of $\mathrm{Bi} / \mathrm{Bi}_{2} \mathrm{O}_{3}$ in XRD profiles (Fig. 1d). However, the observation of sharp Pt peaks $\left(39.7^{\circ}\right.$ and $\left.46.2^{\circ}\right)$ verifies the formation of huge Pt particle in $1 \mathrm{Pt}-$ $\mathrm{SiO}_{2}$. As shown in Fig. 1c, the dopant of bismuth species reaches optimization at $2 \mathrm{wt} . \%$ and the formation of broad diffraction peak of $\mathrm{Bi}_{2} \mathrm{O}_{3}$ for $1 \mathrm{Pt} 5 \mathrm{Bi}-\mathrm{SiO}_{2}$. Therefore, the HAADF-STEM and $\mathrm{XRD}$ results directly indicated that bismuth oxide species as a promoter could phenomenologically prevent the formation of pure huge Pt particles $(50-100 \mathrm{~nm})$ on an inert support $\left(\mathrm{SiO}_{2}\right)$, which is further supported by our density functional theory calculations with more details in the Supplementary Table 2. 

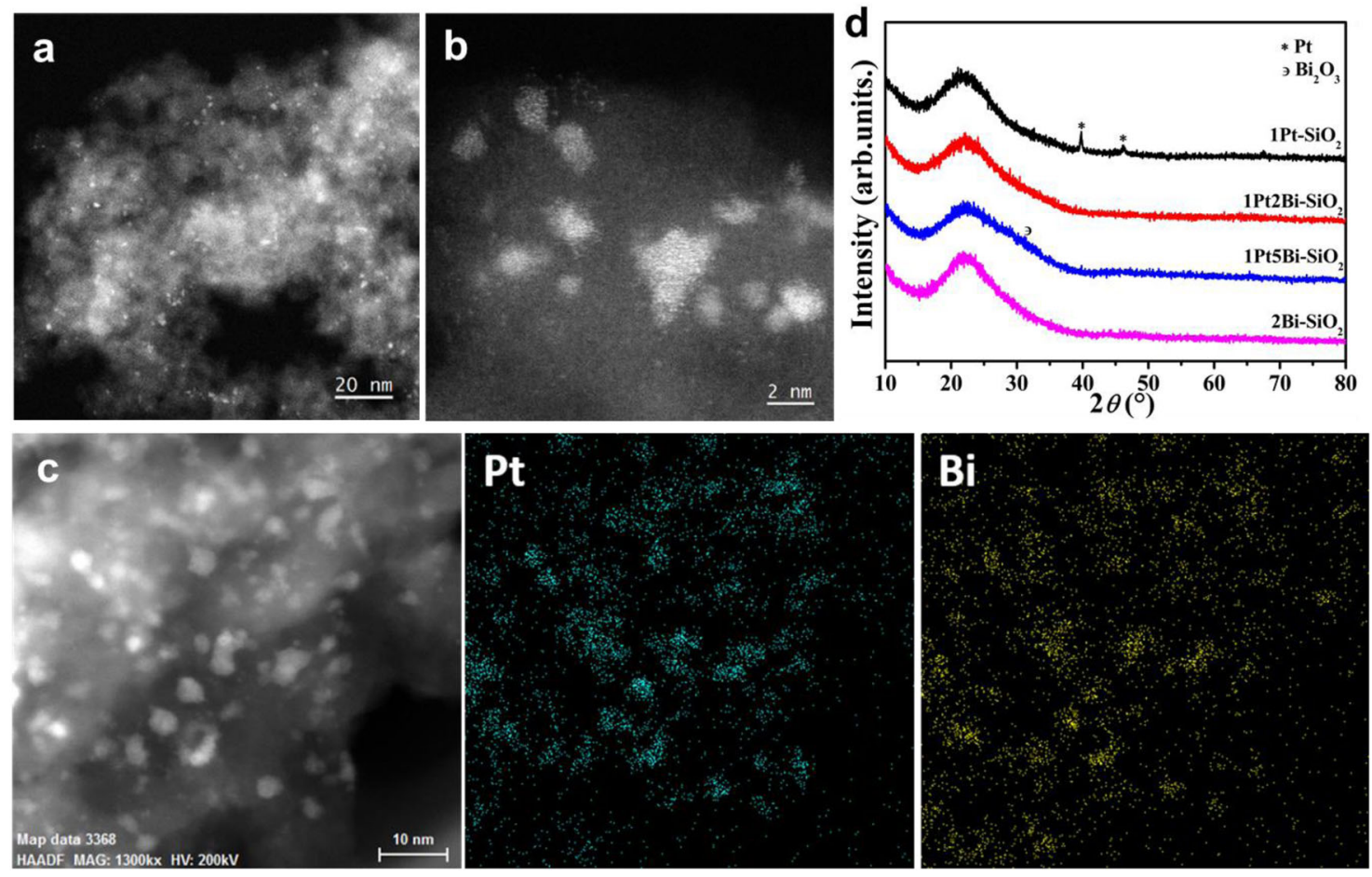

Fig. 1 Structural characterization of $\mathbf{P t} / \mathbf{P t B i}-\mathbf{S i O}_{\mathbf{2}}$ samples. Representative aberration-corrected HAADF-STEM images (a, b) at different scales and corresponding STEM-EDS elemental mapping images $\mathbf{c}$ for fresh $1 \mathrm{Pt} 2 \mathrm{Bi}_{-} \mathrm{SiO}_{2} ; \mathrm{XRD}$ patterns (d) of fresh $\mathrm{Pt} / \mathrm{PtBi}-\mathrm{SiO}_{2}$ samples.
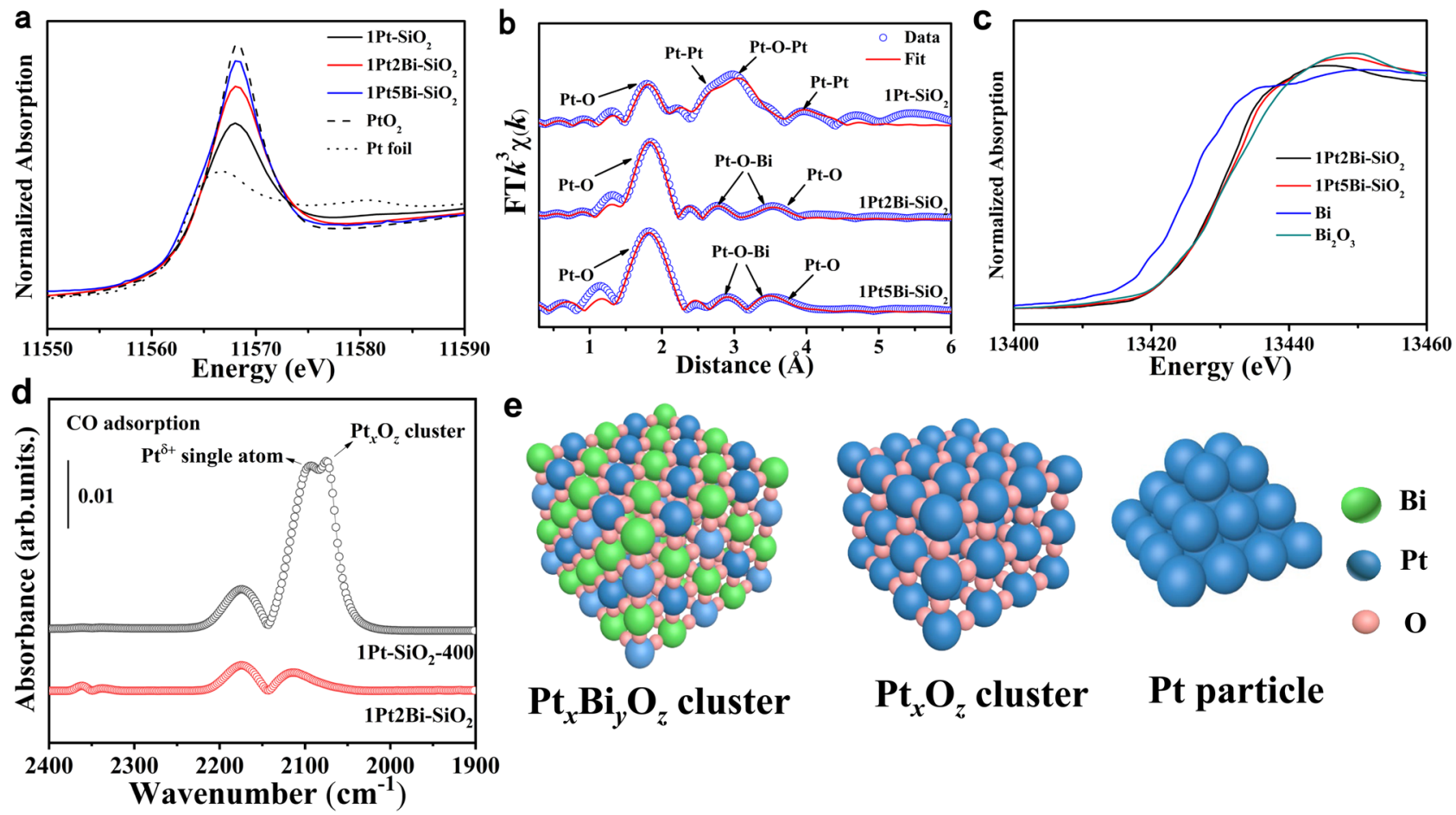

Pt particle

Fig. 2 Local coordination structure of Pt/PtBi-SiO $\mathbf{P}_{\mathbf{2}}$ samples. $P t L_{3}$-edge a XANES profiles, $\mathbf{b}$ EXAFS fitting results in $R$ space and $B i L_{3}$-edge $\mathbf{c} X A N E S$ profiles of $\mathrm{Pt} / \mathrm{PtBi}-\mathrm{SiO}_{2}$ samples; $\mathbf{d}$ in-situ DRIFTS experiments for $\mathrm{CO}$ adsorption of $1 \mathrm{Pt} 2 \mathrm{Bi}^{-} \mathrm{SiO}_{2}$ and $1 \mathrm{Pt}^{-}-\mathrm{SiO}_{2}-400$; e Schematic demonstration on platinum-bismuth oxide clusters, platinum oxide clusters, and metallic Pt particles.

The local coordination structure of platinum and bismuth species. According to aberration-corrected HAADF-STEM images, we can observe the existence of platinum-bismuth oxide clusters. X-ray absorption fine structure (XAFS) technique was applied to clarify the local structure of this cluster in Bi-promoted samples. The X-ray absorption near-edge structure (XANES) of $\mathrm{Pt}-\mathrm{L}_{3}$ edge profiles (Fig. 2a and Supplementary Table 3) showed platinum is in a low valence state $(+1.8)$, due to the formation of 
huge metallic Pt particles in $1 \mathrm{Pt}-\mathrm{SiO}_{2}$. As the increasing of bismuth-dopant, the average oxidation state of platinum arises from 1.8 to 3.5 , because bismuth oxide species could make interaction with platinum to stabilize abundant oxygen around $\mathrm{Pt}$ atom and thus enhancing average valance state of platinum. The extended $\mathrm{X}$-ray absorption fine structure (EXAFS) fitting results (Fig. 2b and Supplementary Table 2$)$ indicated that the major $\mathrm{Pt}-\mathrm{O}(R \approx$ $2.0 \AA, C N \approx 5)$ shell plus an apparent $\mathrm{Pt}-\mathrm{Bi}(R \approx 3.0 \AA$, $C N \approx 4)$ component originated from the $\mathrm{Pt}-[\mathrm{O}]_{x}-\mathrm{Bi}$ structure, further demonstrating the formation of homogeneous oxidized $\mathrm{Pt}_{x} \mathrm{Bi}_{y} \mathrm{O}_{z}$ cluster (Fig. 2e). Meanwhile, the XANES profiles of $\mathrm{Bi}-\mathrm{L}_{3}$ edge (Fig. 2c) and X-ray photoelectron spectroscopy (XPS) spectra display that bismuth species were in the pure $\mathrm{Bi}^{3+}$ state for $\mathrm{Bi}$ promoted samples (Supplementary Fig. 5), which could exclude the possibility of forming $\mathrm{PtBi}$ alloy. While for $1 \mathrm{Pt}-\mathrm{SiO}_{2}$, without strong interaction between $\mathrm{Pt}$ and $\mathrm{SiO}_{2}$, a dominant $\mathrm{Pt}-\mathrm{Pt}$ metallic shell $(R \approx 2.8 \AA, C N \approx 6.4)$ from metallic Pt particle and a minor $\mathrm{Pt}-\mathrm{O}-\mathrm{Pt}$ shell $(R \approx 3.1 \AA, C N \approx 2.7)$ from small-size $\mathrm{Pt}_{x} \mathrm{O}_{z}$ cluster could be determined. In addition, in-situ diffuse reflectance infrared Fourier transform spectroscopy (DRIFTS) experiments were frequently employed to detect the existence form of platinum species (single atoms, clusters or particles). As shown in Fig. 2d and Supplementary Fig. 6, only gases $\mathrm{CO}$ peaks was detected for $1 \mathrm{Pt} 2 \mathrm{Bi}-\mathrm{SiO}_{2}$. However, for $1 \mathrm{Pt}-\mathrm{SiO}_{2}-400$ with almost identical oxide cluster size and loading amounts of platinum species (Supplementary Fig. 7) with $1 \mathrm{Pt} 2 \mathrm{Bi}-\mathrm{SiO}_{2}$, two $\mathrm{CO}$ adsorption peaks on $\mathrm{Pt}^{\delta+}$ single atom $\left(2093 \mathrm{~cm}^{-1}\right)$, oxide cluster $\left(2075 \mathrm{~cm}^{-1}\right)^{19}$ were determined. It further evidences the formation of oxidized $\mathrm{Pt}_{x} \mathrm{Bi}_{y} \mathrm{O}_{z}$ cluster, which possesses totally different structural composition and adsorption capacity with $\mathrm{Pt}_{x} \mathrm{O}_{z}$ cluster in Fig. 2e. To our best knowledge, it is the first time to observe the formation of uniform platinum-bismuth oxide clusters to suppress the aggregation of Pt species.
Catalytic performance of $\mathrm{Pt} / \mathrm{PtBi}-\mathrm{SiO}_{2}$ catalysts in $\mathrm{CO}$ oxidation. CO oxidation was applied as a model reaction to investigate the role of bismuth-dopant. To mimic lean-burn diesel engine exhaust and acquire the best catalytic performance, we used excess $\mathrm{O}_{2}$ in the reactant $\left(\mathrm{CO} / \mathrm{O}_{2}=1 / 20\right)^{30}$. A gas hourly space velocity of $134,000 \mathrm{ml} \mathrm{g}_{\mathrm{cat}}{ }^{-1}$ per hour was tried to match standard vehicle exhaust conditions. When the catalysts were pretreated at $300^{\circ} \mathrm{C}$ under air, Bi-free and Bi-promoted samples show almost same $\mathrm{CO}$ oxidation activity with complete $\mathrm{CO}$ conversion at $\sim 220^{\circ} \mathrm{C}$ (Supplementary Fig. 8), may due to poor ability to adsorb $\mathrm{CO}$ or overhigh valence of platinum species ${ }^{31}$. However, we found that hydrogen reduction significantly enhanced $\mathrm{CO}$ oxidation activity for Bi-promoted catalysts (Fig. 3a). The temperature of $50 \%$ CO conversion dropped off from 165 to $85^{\circ} \mathrm{C}$ as the reduction temperature increasing from 0 to $210^{\circ} \mathrm{C}$. Interestingly, a platform appeared as hydrogen reduction at 150 and $180^{\circ} \mathrm{C}$, indicating a structure transformation of active site occurred during the hydrogen reduction compared with fresh Bi-doped catalysts. On the basis of the CO oxidation activity (Fig. 3b), a remarkable promotion to platinum-silica catalysts was observed by the addition of Bi oxide species with similar Pt loading ( $0.9 \mathrm{wt}$. $\%)$. The catalytic performance reaches the maximum at the dopant of 2 wt.\% (Supplementary Fig. 9), due to overmuch bismuth oxide species hindering $\mathrm{CO}$ adsorption or covering platinum active site. For comparison, pure $\mathrm{Bi}$ catalyst $\left(2 \mathrm{Bi}-\mathrm{SiO}_{2}\right)$ shows no $\mathrm{CO}$ oxidation activity below $160^{\circ} \mathrm{C}$ (Fig. $3 \mathrm{~b}$ ), demonstrating bismuth species is not active site, just as secondary dopant to modification platinum active site. Furthermore, we collected the kinetic data to compare the inherent catalytic activity. The specific activity normalized by the platinum amount for $1 \mathrm{Pt} 2 \mathrm{Bi}-\mathrm{SiO}_{2}$ was $487 \mu \mathrm{mol}_{\mathrm{CO}} \mathrm{g}_{\mathrm{Pt}}{ }^{-1} \mathrm{~s}^{-1}$ at $110^{\circ} \mathrm{C}$, as active as the reported $\mathrm{Pt} / \mathrm{CeO}_{2}$ catalysts $\left(103-518 \mu \mathrm{mol}_{\mathrm{CO}} \mathrm{g}_{\mathrm{Pt}}{ }^{-1} \mathrm{~s}^{-1}\right.$ at 80 $-130^{\circ} \mathrm{C}$, see Table 1 ), as well as 10 times higher than that of pure

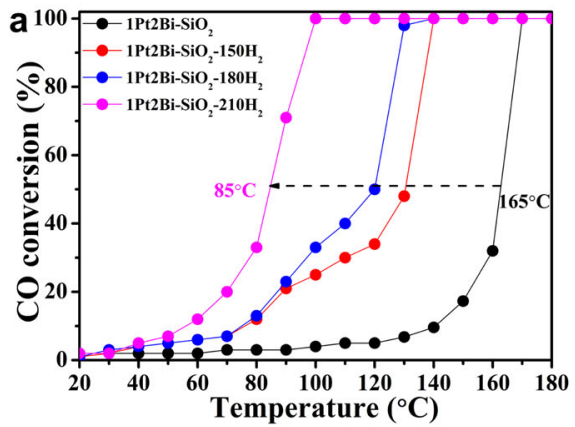

d
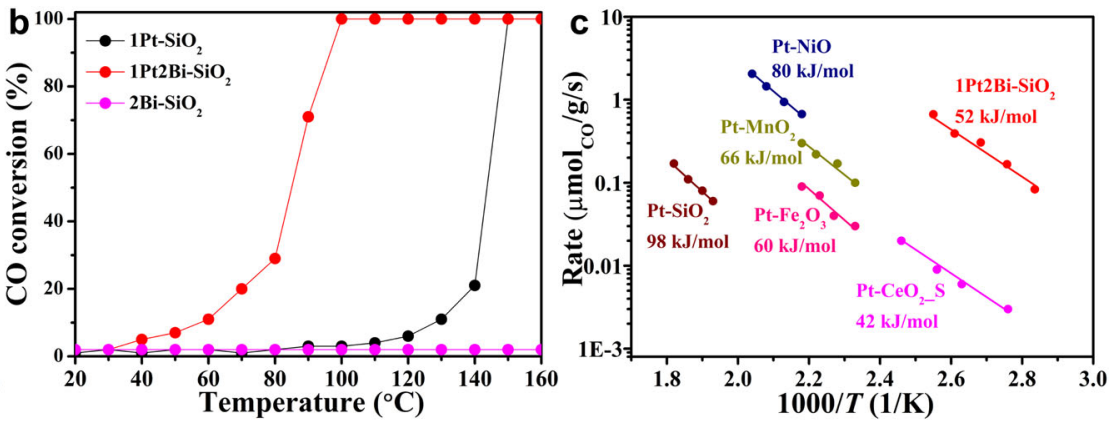

${ }_{20}$ Time on steam $(h)_{40}$

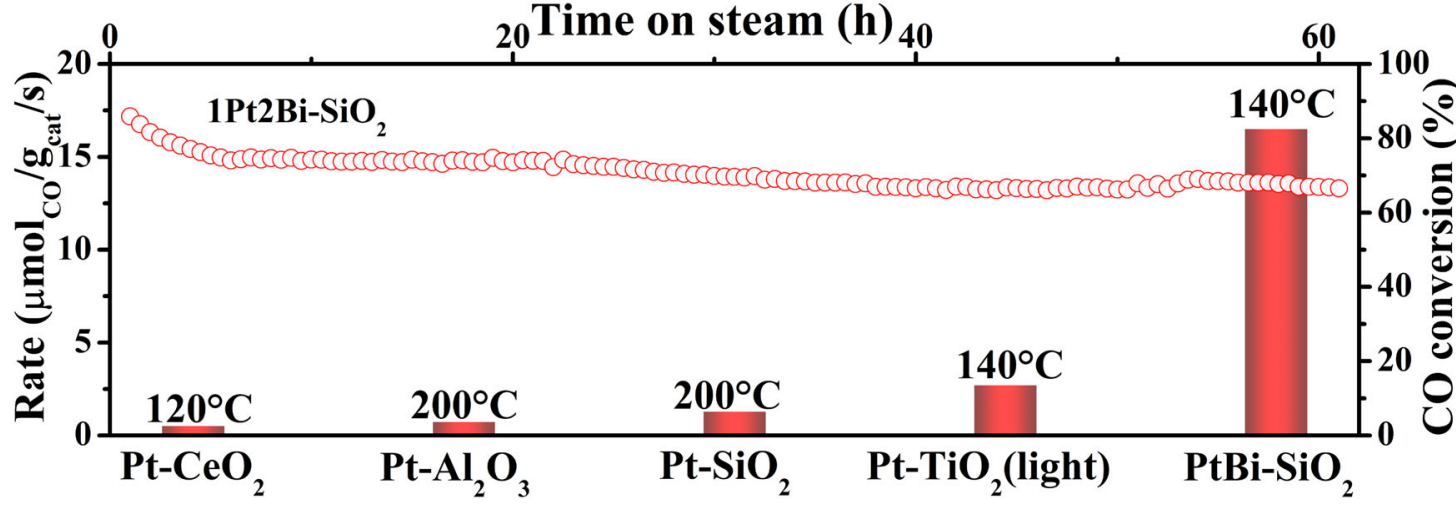

Fig. 3 Catalytic performance of $\mathbf{P t} / \mathbf{P t B i}-\mathrm{SiO}_{\mathbf{2}}$ catalysts in $\mathbf{C O}$ oxidation. a $\mathrm{CO}$ oxidation experiments with different $\mathrm{H}_{2}$-pretreatment temperature for $1 \mathrm{Pt} 2 \mathrm{Bi}-\mathrm{SiO}_{2} ; \mathbf{b}$ Catalytic $\mathrm{CO}$ oxidation light-off performance of different catalysts at a gas hourly space velocity of $134,000 \mathrm{~mL} \mathrm{~g}_{\text {cat }}{ }^{-1} \mathrm{~h}^{-1}$ in 1 vol. $\% \mathrm{CO} / 20$ vol.\% $\mathrm{O}_{2} / 79$ vol. $\% \mathrm{~N}_{2}$. Temperature ramp: $2{ }^{\circ} \mathrm{C} \mathrm{min}{ }^{-1}$; c Apparent activation energy $\left(E_{\mathrm{a}}\right)$ of various catalysts; $\mathbf{d} \mathrm{CO}$ oxidation stability test $\left(150{ }^{\circ} \mathrm{C}\right.$, $200,000 \mathrm{~mL} \mathrm{~g}^{-1} \mathrm{~h}^{-1}$ ) and reaction rate of different catalysts. 
Table 1 Comparison of the activities over the representative platinum catalysts for the oxidation of carbon monoxide.

\begin{tabular}{|c|c|c|c|c|c|c|}
\hline & Temp $\left({ }^{\circ} \mathrm{C}\right)$ & Gas feed composition & $r_{1}$ & $r_{2}$ & Apparent activation energy $(\mathrm{kJ} / \mathrm{mol})$ & Ref. \\
\hline \multicolumn{7}{|l|}{ Inert support } \\
\hline 1 wt. $\% \mathrm{Pt} / \theta-\mathrm{Al}_{2} \mathrm{O}_{3}$ & 200 & $3.7 \% \mathrm{CO} / 3.7 \% \mathrm{O}_{2} / \mathrm{He}$ & 0.7 & 72 & - & 57 \\
\hline 0.5 wt. $\% \mathrm{Pt} / \mathrm{SiO}_{2}$ & 200 & 40TorrCO/100 TorrO $2 / \mathrm{He}$ & 1.3 & 256 & 95 & 4 \\
\hline \multicolumn{7}{|l|}{ Reducible support } \\
\hline 1 wt. $\% \mathrm{Pt} / \mathrm{CeO}_{2}$ & 225 & $2 \% \mathrm{CO} / 1 \% \mathrm{O}_{2} / \mathrm{N}_{2}$ & 8.7 & 871 & 55 & 32 \\
\hline 0.5 wt. $\% \mathrm{Pt} / \mathrm{Fe}_{2} \mathrm{O}_{3}$ & & & 1.7 & 349 & 70 & \\
\hline 0.5 wt. $\% \mathrm{Pt} / \mathrm{CeO}_{2}$ & & & 6.9 & 1384 & 63 & \\
\hline $1 \mathrm{wt} \% \mathrm{Pt} / \mathrm{CeO}_{2}$ & 134 & $0.4 \% \mathrm{CO} / 10 \% \mathrm{O}_{2} / \mathrm{He}$ & 1.0 & 103 & 43 & 2 \\
\hline $1 \mathrm{wt} \% \mathrm{Pt} / \mathrm{CeO}_{2}$ & 80 & $1.9 \% \mathrm{CO} / 1.2 \% \mathrm{O}_{2} / \mathrm{He}$ & 5.2 & 518 & 30 & 59 \\
\hline $0.22 \mathrm{Pt} / \mathrm{CeO}_{2}$ & 110 & $1 \% \mathrm{CO} / 20 \% \mathrm{O}_{2} / \mathrm{He}$ & 0.2 & 92 & - & 23 \\
\hline \multicolumn{7}{|l|}{ Our results } \\
\hline \multirow[t]{2}{*}{ 1Pt2Bi-SiO 2} & 90 & $1 \% \mathrm{CO} / 20 \% \mathrm{O}_{2} / \mathrm{N}_{2}$ & 1.7 & 210 & 50 & This work \\
\hline & 225 & & 58.3 & 7289 & & \\
\hline
\end{tabular}

Pt catalyst (Supplementary Table 4). For eliminating size-effect on active site, $1 \mathrm{Pt}-\mathrm{SiO}_{2}-400$ was similarly inactive for $\mathrm{CO}$ oxidation reaction with complete conversion of $\mathrm{CO}$ at $200^{\circ} \mathrm{C}$ (Supplementary Fig. 9b), though possessing similar cluster size $(1.8 \pm 0.1 \mathrm{~nm})$ to $1 \mathrm{Pt} 2 \mathrm{Bi}-\mathrm{SiO}_{2}$ (Supplementary Fig. 7). It indicates that the dispersion of platinum species does not dominantly determines the $\mathrm{CO}$ oxidation activity. In another hand, the apparent activation energy $\left(E_{\mathrm{a}}\right)$ of $\mathrm{Bi}$-promoted platinum catalysts $\left(\sim 52 \mathrm{~kJ} \mathrm{~mol}^{-1}\right)$ is similar to that of $\mathrm{CeO}_{2}$-supported Pt catalyst $\left(40-50 \mathrm{~kJ} \mathrm{~mol}^{-1}\right)^{2,32}$, and distinctly lower than that of pure $1 \mathrm{Pt}$ $\mathrm{SiO}_{2} \quad\left(\sim 70 \mathrm{~kJ} \mathrm{~mol}^{-1}\right)$ and other inert support platinum catalysts $^{5,33}$ (Fig. 3c). This may give a hint on the totally different reaction mechanism or active site for our Bi-promoted $\mathrm{Pt}-\mathrm{SiO}_{2}$ catalysts. Additionally, $1 \mathrm{Pt} 2 \mathrm{Bi}-\mathrm{SiO}_{2}$ showed remarkable thermostability for $\sim 70 \mathrm{~h}$ at $150{ }^{\circ} \mathrm{C}$ and $200,000 \mathrm{~mL} \mathrm{~g}^{-1} \mathrm{~h}^{-1}$ in $1 \% \mathrm{CO} /$ $20 \% \mathrm{O}_{2} / \mathrm{N}_{2}$ (Fig. 3d) and catalytic stability at high temperature $\left(500{ }^{\circ} \mathrm{C}\right)$ under the high space velocity to maintain the CO conversion at $95 \%\left(300,000 \mathrm{~mL} \mathrm{~g}_{\mathrm{cat}}{ }^{-1} \mathrm{~h}^{-1}\right.$, Supplementary Fig. 9c).

Structural characterization of used $\mathrm{Pt} / \mathrm{PtBi}-\mathrm{SiO}_{2}$ catalysts. After CO oxidation, we employed a comprehensive characterization to determine the actual structure of active site. The aberrationcorrected HAADF-STEM images (Fig. 4a-c and Supplementary Fig. 10) showed that the platinum species was still in the formation of cluster $(\sim 2 \mathrm{~nm})$ without any visible lattice fringes of crystal $\mathrm{Pt} / \mathrm{PtO} / \mathrm{PtO}_{2}$ component after $\mathrm{CO}$ oxidation. Meanwhile, the related STEM-EDS mapping results of cluster indicated that the $\mathrm{Pt}$ and $\mathrm{Bi}$ elements are still distributed together, not core-shell at the same area (Fig. $4 \mathrm{~d}$ and Supplementary Fig. 11). Thus, the bismuth element around platinum cluster still makes an interaction with platinum species to prevent aggregation of clusters into huge particles, even after hydrogen reduction. In another hand, there is an obvious aggregation of platinum cluster $(\sim 3.0 \mathrm{~nm})$ compared to fresh $1 \mathrm{Pt}_{-} \mathrm{SiO}_{2}(\sim 1.7 \mathrm{~nm})$ in Supplementary Fig. 10c. Mahmudov and co-workers found obvious aggregation of platinum particles on activated carbon after hydrogen reduction ${ }^{34}$. The XRD results in Fig. $4 \mathrm{e}$ also confirmed the huge metallic platinum particles were still maintained in $1 \mathrm{Pt}$ $\mathrm{SiO}_{2}$ with sharp diffraction peaks at $39.7^{\circ}$ and $46.2^{\circ}$. In contrast, no obvious diffraction peaks of $\mathrm{Pt} / \mathrm{PtO} / \mathrm{PtO}_{2}$ phases were detected in Bi-promoted samples, further confirming the high dispersion of platinum species. There was a broad peak of $\mathrm{Bi}_{2} \mathrm{O}_{3}$ in $1 \mathrm{Pt} 5 \mathrm{Bi}-$ $\mathrm{SiO}_{2}$, due to the aggregation of bismuth species.

According to the catalytic performance in $\mathrm{CO}$ oxidation with hydrogen reduction pretreatment, an obvious structural evolution occurred in Bi-promoted catalysts. Recently, more and more reports indicate that in-situ or quasi in-situ techniques cloud seize the evolution of active site and the synergistic effect on bimetal catalysts $^{35-38}$. The quasi in-situ XAFS experiment could acquire a good signal-noise ratio of XAFS spectrum for low content of metal and retain the real structure of active site under different condition. In order to elucidate the real active site structure in reductive and $\mathrm{CO}$ oxidation atmosphere, XAFS spectrums of $1 \mathrm{Pt}-\mathrm{SiO}_{2}$ and $1 \mathrm{Pt} 2 \mathrm{Bi}-\mathrm{SiO}_{2}$ were collected after hydrogen reduction at different temperature $\left(150\right.$ and $\left.210^{\circ} \mathrm{C}\right)$ and $1 \mathrm{~h}$ of time-on-stream in $\mathrm{CO}$ oxidation $\left(100^{\circ} \mathrm{C}\right)$ in a stainless reactor with two globe valves and tableting in glove box under nitrogen atmosphere and ambient temperature for further XAFS experiments without exposure to air.

Combination with the catalytic performance in Fig. $3 a$ and previous reported ${ }^{31,39}$, the lower oxidized state of $\mathrm{Pt}$ species is appropriate for lower temperature CO oxidation. XANES data in Fig. 5a, c indicated that the valance state of platinum species is decreasing $\left(+1.2\right.$ to +0.2 and +2.5 to +0.4 for $1 \mathrm{Pt}-\mathrm{SiO}_{2}$ and $1 \mathrm{Pt} 2 \mathrm{Bi}-\mathrm{SiO}_{2}$ respective) as the increasing of hydrogen reduction temperature $\left(150-210^{\circ} \mathrm{C}\right)$ (Supplementary Table 5). The corresponding XANES profiles during $\mathrm{CO}$ oxidation following the hydrogen reduction at $210^{\circ} \mathrm{C}$ were collected in Fig. 5a, c, the average valance of platinum slightly increases from +0.2 to +1.0 and +0.4 to +1.3 for $1 \mathrm{Pt}-\mathrm{SiO}_{2}$ and $1 \mathrm{Pt} 2 \mathrm{Bi}-\mathrm{SiO}_{2}$ respective compared with that in reduced state at $210^{\circ} \mathrm{C}$. It demonstrated that the oxygen-rich reaction gas could make platinum species slight oxidative. Meanwhile, the similar valance of platinum species about +1 indicates that the difference in $\mathrm{CO}$ oxidation activity for $1 \mathrm{Pt}-\mathrm{SiO}_{2}$ and $1 \mathrm{Pt} 2 \mathrm{Bi}-\mathrm{SiO}_{2}$ is not mainly due to platinum valance. Furthermore, the relevant EXAFS profiles were exhibited in Fig. $5 c$, d. For $1 \mathrm{Pt}-\mathrm{SiO}_{2}$, after hydrogen reduction, a main metallic $\mathrm{Pt}-\mathrm{Pt}$ shell $(R \approx 2.75 \AA, C N \approx 7.0-9.2)$ was acquired and only a minor $\mathrm{Pt}-\mathrm{O}$ shell $(R \approx 2.00 \AA, C N \approx 0.6)$ can be fitted 
a

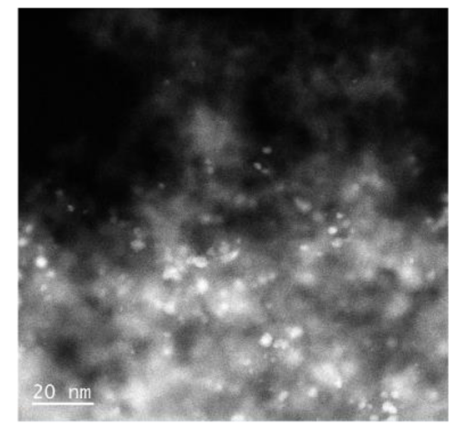

d
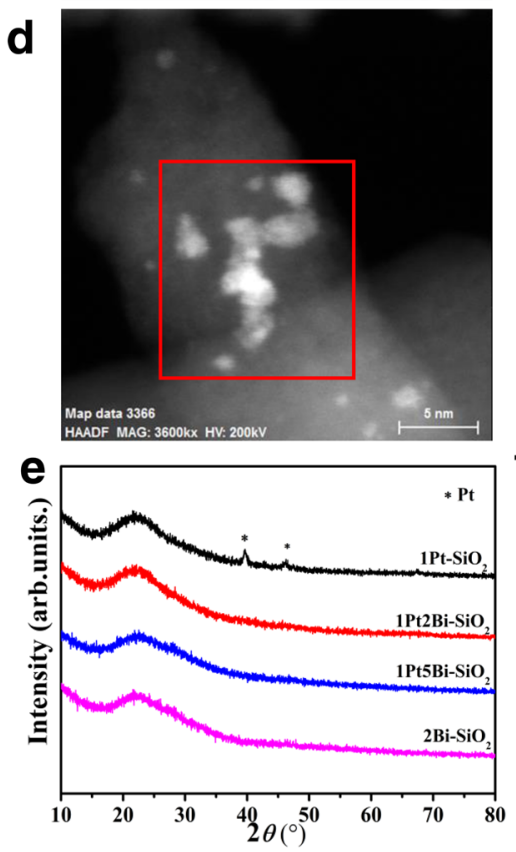
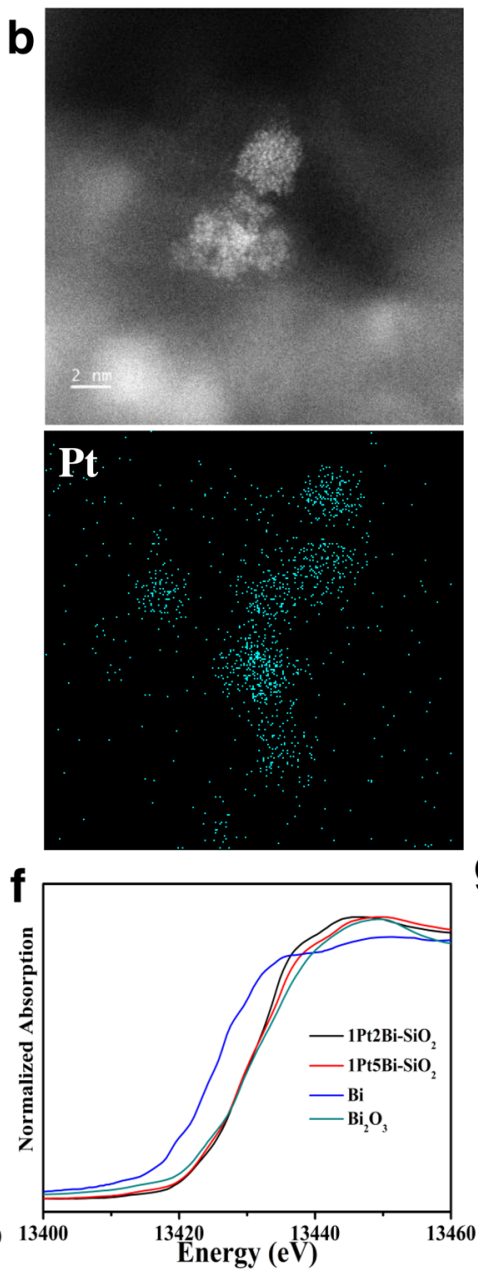
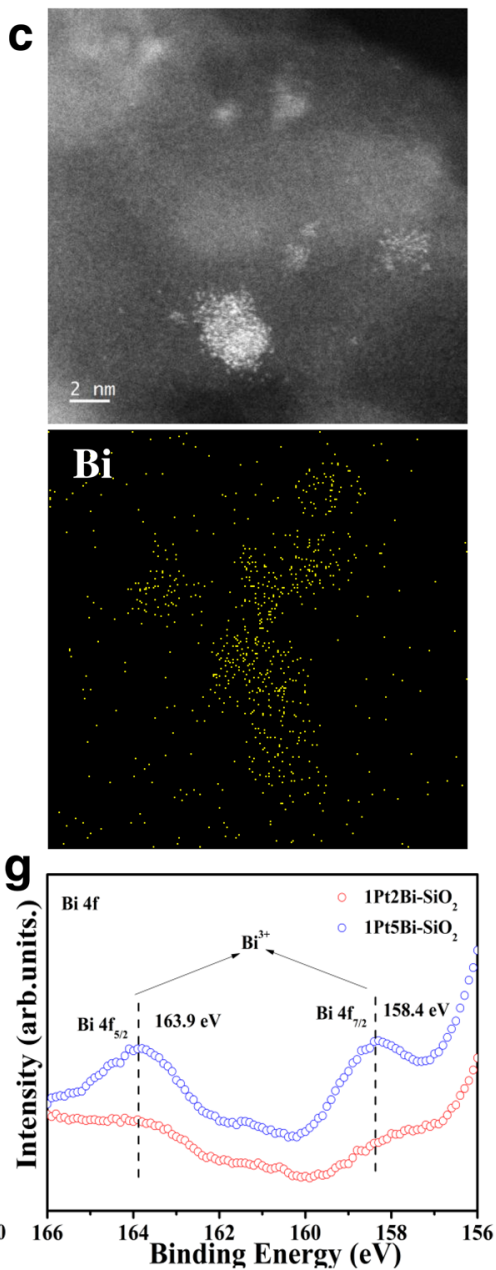

Fig. 4 Structural characterization of used Pt/PtBi-SiO $\mathbf{~}_{\mathbf{2}}$ catalysts. Representative aberration-corrected HAADF-STEM images of a-c for used 1 Pt2Bi-SiO 2 at different scales and $\mathbf{d}$ the corresponding EDS element mapping of used $1 \mathrm{Pt} 2 \mathrm{Bi}_{-} \mathrm{SiO}_{2} ; \mathbf{e}$ XRD patterns; $\mathrm{Bi}_{\mathrm{L}_{3}}$-edge $\mathbf{f}$ XANES profiles and $\mathbf{g}$ XPS profiles of used $\mathrm{Pt} / \mathrm{PtBi}-\mathrm{SiO}_{2}$ samples.

at low reduction temperature $\left(150^{\circ} \mathrm{C}\right)$, which may result in low activity due to no surface-active oxygen to participate in $\mathrm{CO}$ oxidation ${ }^{40}$. For $1 \mathrm{Pt} 2 \mathrm{Bi}-\mathrm{SiO}_{2}$, in order to require more reliable local coordination structure, we conducted the EXAFS fitting process with or without $\mathrm{Pt}-\mathrm{O}-\mathrm{Bi}$ shell in Supplementary Fig. 13. Obviously, $\mathrm{Pt}-\mathrm{O}-\mathrm{Bi}$ shell is an essential composition to acquire the most reasonable fitting results. In Fig. 5d and Supplementary Table 5, there is an obvious difference in local coordination structure compared with $1 \mathrm{Pt}-\mathrm{SiO}_{2}$. When the reduction temperature is at $150^{\circ} \mathrm{C}$, only partial platinum species is reduced to metallic Pt with a small $C N \approx 4.8$ at $R \approx 2.75 \AA$, plus strong $\mathrm{Pt}-\mathrm{O}$ $(R \approx 2.00 \AA, C N \approx 2.1)$ and $\mathrm{Pt}-\mathrm{O}-\mathrm{Bi}(R \approx 2.98 \AA, C N \approx 1.8)$ shells. It proves the $\mathrm{CO}$ conversion platform of $1 \mathrm{Pt} 2 \mathrm{Bi}_{-} \mathrm{SiO}_{2}$ in Fig. $3 \mathrm{a}$ is due to incomplete evolution of active site at $150^{\circ} \mathrm{C}$. Furthermore, there is similar coordination structure for $1 \mathrm{Pt} 2 \mathrm{Bi}-\mathrm{SiO}_{2}-210^{\circ} \mathrm{C}$ and $1 \mathrm{Pt} 2 \mathrm{Bi}-\mathrm{SiO}_{2}-\mathrm{CO}$ oxidation, indicating the reduction temperature at $210^{\circ} \mathrm{C}$ is appropriate for construction of optimal active sites. The EXAFS fitting results for $\mathrm{Pt}-\mathrm{Pt}$ shell with $C N \approx 7.4$ also confirmed the average grain size of platinum cluster was $\sim 2 \mathrm{~nm}$ for $1 \mathrm{Pt} 2 \mathrm{Bi}-\mathrm{SiO}_{2}{ }^{41}$ as observed in HAADF-STEM images (Fig. $4 \mathrm{a}-\mathrm{c}$ ). In addition, we found that the $\mathrm{Pt}-\mathrm{O} \quad(R \approx 2.00 \AA, C N \approx 1.5)$ of $1 \mathrm{Pt} 2 \mathrm{Bi}^{-} \mathrm{SiO}_{2}$ - $\mathrm{CO}$ oxidation is higher than that $(R \approx 1.98 \AA, C N \approx 0.6)$ of $1 \mathrm{Pt} 2 \mathrm{Bi}^{-} \mathrm{SiO}_{2}-210^{\circ} \mathrm{C}$, may due to the formation of more $\mathrm{Pt}-[\mathrm{O}]_{x}-\mathrm{Bi}$ structure in oxidative atmosphere. And the detection of $\mathrm{Pt}-\mathrm{O}-\mathrm{Bi}(R \approx 3.00$ $\AA ̊ ., C N \approx 2.3$ ) composition (Fig. 5d and Supplementary Table 3) also validates the existence of $\mathrm{Pt}-[\mathrm{O}]_{x}-\mathrm{Bi}$ structure. Thus, the clusters in $1 \mathrm{Pt} 2 \mathrm{Bi}-\mathrm{SiO}_{2}$ observed in aberration-corrected HAADF-STEM images (Fig. $4 \mathrm{a}-\mathrm{c}$ ) is metallic platinum cluster. In another hand, the $\mathrm{Bi}_{3}$ XANES and $\mathrm{Bi}$ 4f XPS profiles in Fig. 4f, g indicate that bismuth species is still in oxidative state even after hydrogen reduction and $\mathrm{CO}$ oxidation, which can exclude the formation of $\mathrm{PtBi}$ alloy. As a reference, $1 \mathrm{Pt}-\mathrm{SiO}_{2}-400$ exhibited low activity in CO oxidation (Supplementary Fig. 9b), even though possessing similar local coordination structure for $\mathrm{Pt}-\mathrm{O}$ and $\mathrm{Pt}-\mathrm{Pt}$ shell to the used $1 \mathrm{Pt} 2 \mathrm{Bi}-\mathrm{SiO}_{2}$ (Supplementary Fig. 14b). Thus, taking the consideration of the similar valance state for Pt in $1 \mathrm{Pt}-\mathrm{SiO}_{2}$ and $1 \mathrm{Pt} 2 \mathrm{Bi}-\mathrm{SiO}_{2}(\sim+1.0)$, we can draw a conclude that the surface $\mathrm{Pt}-[\mathrm{O}]_{x}-\mathrm{Bi}$ structure plays a key role in low temperature $\mathrm{CO}$ oxidation reaction rather than solo oxidized $\mathrm{Pt}_{x} \mathrm{O}_{z}$ cluster.

The reducibility and active oxygen for $\mathrm{Pt} / \mathrm{PtBi}-\mathrm{SiO}_{2}$. As we know, the reducibility of catalysts is crucial in various redox reactions $s^{42-44}$. For fresh samples, a main reduction peak located at $\sim 100^{\circ} \mathrm{C}$ appeared on profiles of $\mathrm{H}_{2}-$ temperature programmed reduction $\left(\mathrm{H}_{2}-\mathrm{TPR}\right)$ in Fig. $6 \mathrm{a}$ for $1 \mathrm{Pt}-\mathrm{SiO}_{2}$ contributed by the reduction of $\mathrm{Pt}_{x} \mathrm{O}_{z}$ clusters ${ }^{45}$. However, for Bi-doped samples, the first broad reduction peak was shifted to $162^{\circ} \mathrm{C}\left(1 \mathrm{Pt} 2 \mathrm{Bi}-\mathrm{SiO}_{2}\right)$ and $197^{\circ} \mathrm{C}\left(1 \mathrm{Pt} 5 \mathrm{Bi}-\mathrm{SiO}_{2}\right)$ in Supplementary Fig. $15 \mathrm{a}$, due to the strong interaction of $\mathrm{Pt}-\mathrm{O}-\mathrm{Bi}^{46}$, as confirmed by EXAFS fitting 

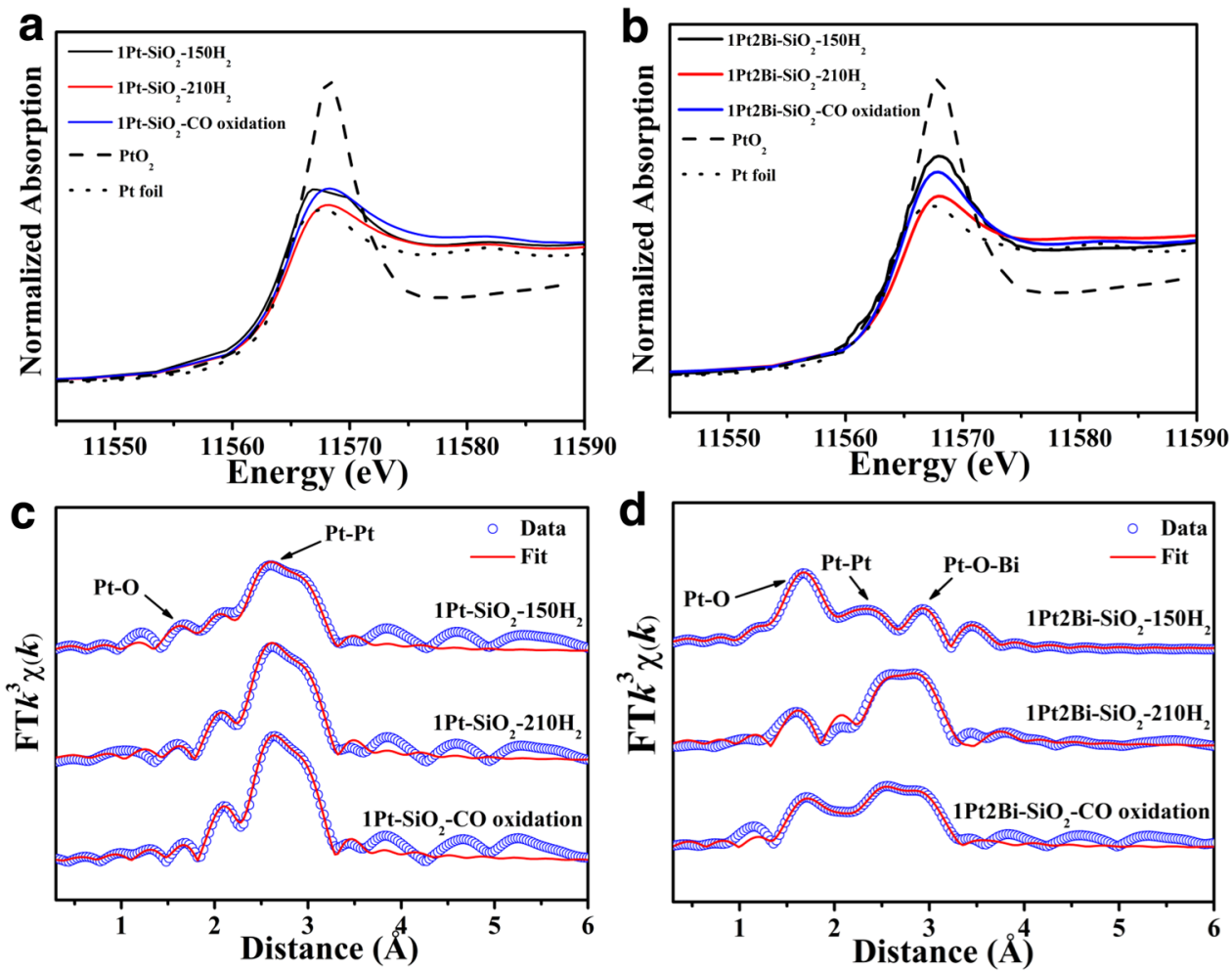

Fig. 5 The local coordination structure of Pt/PtBi-SiO $\mathbf{~}_{\mathbf{2}}$ catalysts. Quasi in-situ Pt $\mathrm{L}_{3}$-edge $\mathbf{a}, \mathbf{c} X A N E S$ profiles and $\mathbf{b}$, $\mathbf{d}$ EXAFS fitting results in $R$ space for $1 \mathrm{Pt}-\mathrm{SiO}_{2}(\mathbf{a}, \mathbf{b})$ and $1 \mathrm{Pt} 2 \mathrm{Bi}^{-} \mathrm{SiO}_{2}(\mathbf{c}, \mathbf{d})$ under specific conditions.
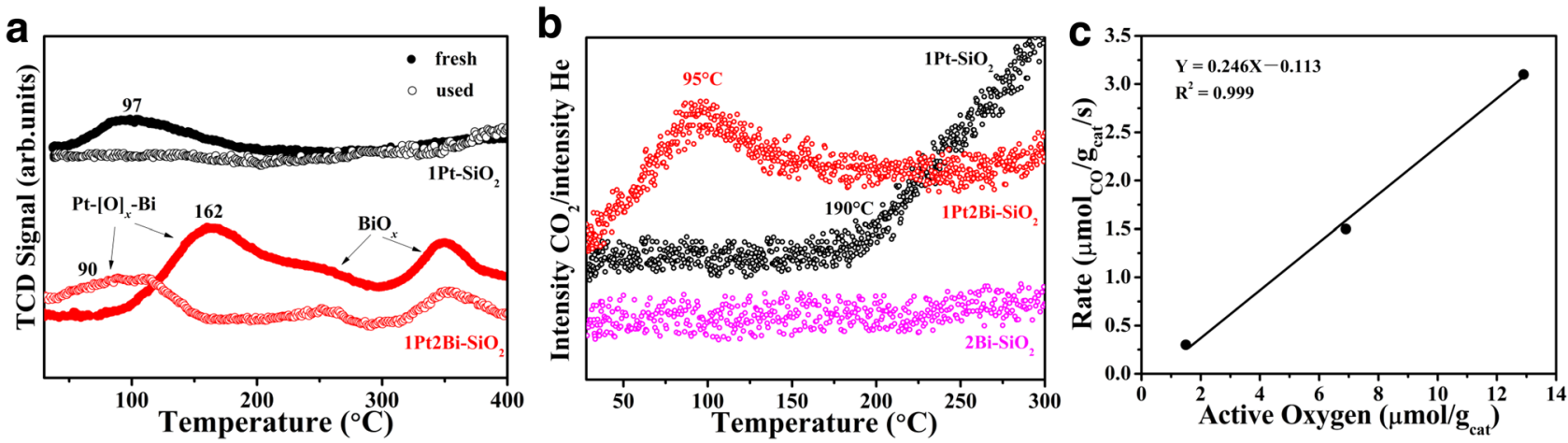

Fig. 6 The reducible property and active oxygen for $\mathbf{P t} / \mathbf{P t B i}-\mathrm{SiO}_{\mathbf{2}} \cdot \mathbf{a} \mathrm{H}_{2}-\mathrm{TPR}$ profiles of fresh $\mathrm{Pt} / \mathrm{PtBi}-\mathrm{SiO}_{2}$ catalysts and used catalysts after $\mathrm{CO}$ oxidation without exposure to air; $\mathbf{b}$ in-situ $\mathrm{CO}-\mathrm{TPR}$ of used $\mathrm{Pt} / \mathrm{PtBi}-\mathrm{SiO}_{2}$ samples after $\mathrm{CO}$ oxidation without exposure to air; $\mathbf{c}$ linear equation for active oxygen vs reaction rate for used $\mathrm{Pt} / \mathrm{PtBi}-\mathrm{SiO}_{2}$ samples.

results. The hydrogen consumption values (Supplementary Table 6) increased for $107 \mu \mathrm{mol} / \mathrm{g}\left(1 \mathrm{Pt}-\mathrm{SiO}_{2}\right)$ to $185 \mu \mathrm{mol} / \mathrm{g}$ $\left(1 \mathrm{Pt} 2 \mathrm{Bi}-\mathrm{SiO}_{2}\right)$. Although the doping of bismuth oxide species can enhance the surface oxygen, there is no promotion in $\mathrm{CO}$ oxidation. Because the over-strong interaction between platinum and bismuth $(\mathrm{Pt}-\mathrm{O}-\mathrm{Bi})$ cannot release oxygen atom to take part in reaction. $\mathrm{CO}$-temperature programmed reduction (CO-TPR) results in Supplementary Fig. 16 also demonstrated the surfaceactive oxygen for $1 \mathrm{Pt} 2 \mathrm{Bi}-\mathrm{SiO}_{2}(\sim 75 \mu \mathrm{mol} / \mathrm{g})$ is almost two times than that $(\sim 40 \mu \mathrm{mol} / \mathrm{g})$ of $1 \mathrm{Pt}-\mathrm{SiO}_{2}$. However, these oxygen species only reacted with $\mathrm{CO}$ molecule above $100^{\circ} \mathrm{C}$, well consistent with low activity in $\mathrm{CO}$ oxidation with oxidative pretreatment (Supplementary Fig. 8).

We also carried out the $\mathrm{H}_{2}$-TPR and $\mathrm{CO}-\mathrm{TPR}$ experiments for used $\mathrm{Pt} / \mathrm{PtBi}-\mathrm{SiO}_{2}$ samples after $\mathrm{CO}$ oxidation without air exposure absolutely to detect reducibility and active oxygen of active site. For $\mathrm{H}_{2}-\mathrm{TPR}$ experiments, no reduction peak below $200^{\circ} \mathrm{C}$ appeared in $1 \mathrm{Pt}-\mathrm{SiO}_{2}$ due to hydrogen reduction treatment before reaction. However, a broad reduction peak starting from $50^{\circ} \mathrm{C}$ still existed in Bi-doped samples, indicating the existence of $\mathrm{Pt}-[\mathrm{O}]_{x}-\mathrm{Bi}$ structure with low oxidation state of platinum. It indicates the unique active site of platinum cluster with surface $\mathrm{Pt}-[\mathrm{O}]_{x}-\mathrm{Bi}$ structure exhibits more reducible property to release oxygen. In addition, there are two reduction peaks at 250 and $350{ }^{\circ} \mathrm{C}$, which are attributed to the high dispersion $\mathrm{BiO}_{x}$ cluster adjoining to platinum cluster and isolated $\mathrm{BiO}_{x}$ cluster deposited on the surface of $\mathrm{SiO}_{2}$. However, the oxygen provided by these $\mathrm{BiO}_{x}$ clusters only can be activated at high temperature $\left(>200^{\circ} \mathrm{C}\right)$, which makes few contributions to low temperature $\mathrm{CO}$ oxidation activity. Additionally, CO-TPR results of used $1 \mathrm{Pt} 2 \mathrm{Bi}^{-} \mathrm{SiO}_{2}$ also evidenced these surface oxygen atoms in $\mathrm{Pt}-[\mathrm{O}]_{x}-\mathrm{Bi}$ structure was superior active to react with $\mathrm{CO}$ molecule generating $\mathrm{CO}_{2}$ from $\sim 50{ }^{\circ} \mathrm{C}$ (Fig. 6b), well consistent with the CO oxidation "light off" temperature (Fig. 3b). 

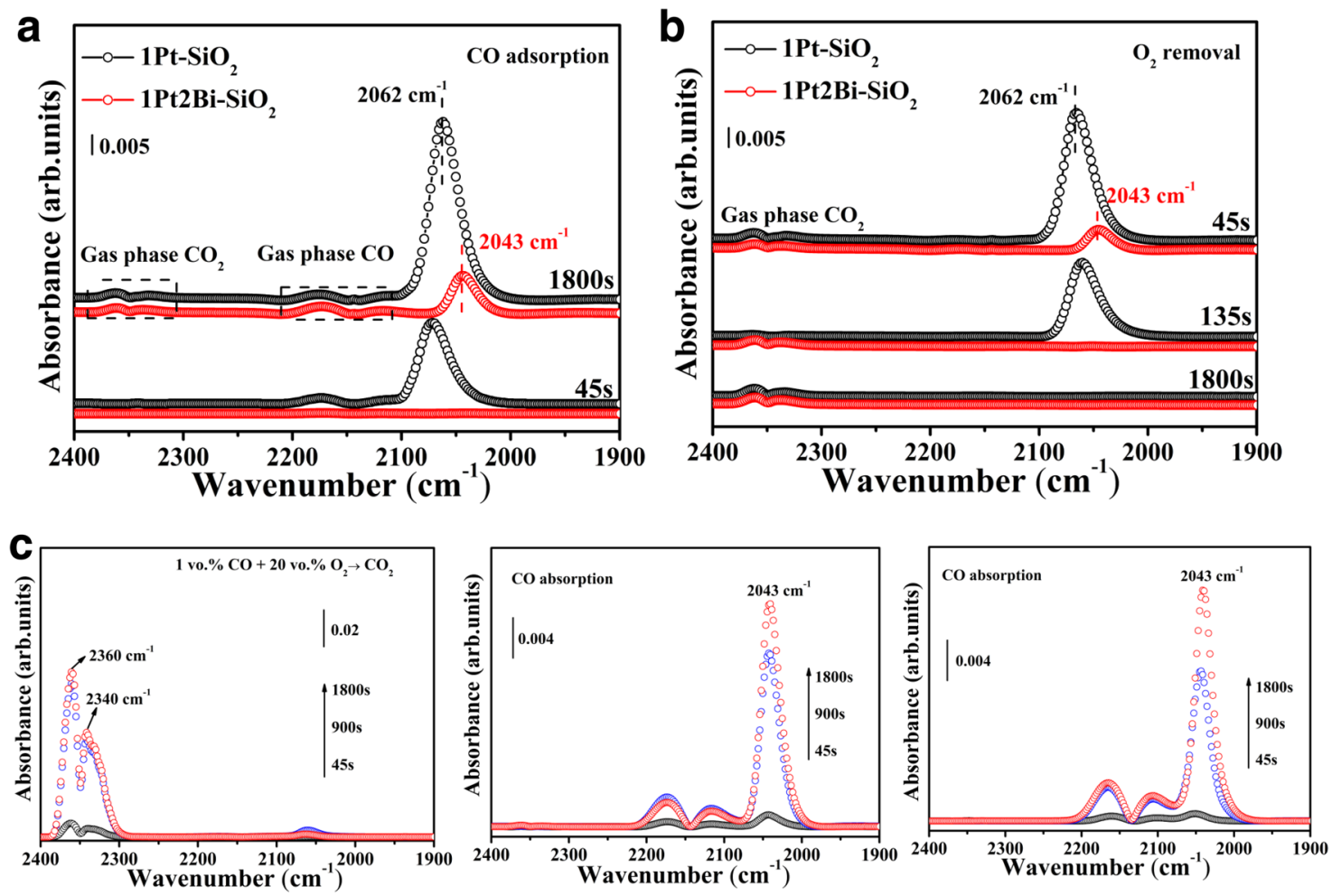

Fig. 7 The $\mathbf{C O}$ adsorption on $\mathbf{P t}-\left[\mathbf{O O}_{\mathbf{x}}-\mathbf{B i}\right.$ active site. In-situ DRIFTS study of a CO adsorption and $\mathbf{b} \mathrm{O}_{2}$ removal on $\mathrm{Pt} / \mathrm{PtBi}-\mathrm{SiO} \mathrm{O}_{2}$ samples; $\mathbf{c}$ In-situ DRIFTS in the mode: "CO adsorption $\rightarrow$ reaction conditions $\left(1 \% \mathrm{CO} / 20 \% \mathrm{O}_{2} / \mathrm{N}_{2}\right.$ flow) at $200{ }^{\circ} \mathrm{C} \rightarrow \mathrm{CO}$ adsorption" on $1 \mathrm{Pt}^{2} \mathrm{Bi}-\mathrm{SiO} \mathrm{O}_{2}$ without catalyst replacement and air exposure. (The catalysts were pretreated in-situ at $210{ }^{\circ} \mathrm{C}$ under $\mathrm{H}_{2}$ flow in the DRIFTS reaction cell before data collection; CO flow rate: $30 \mathrm{~mL} \mathrm{~min}{ }^{-1}$; catalyst mass: $20 \mathrm{mg}$; temperature: $100^{\circ} \mathrm{C}$ ).

However, $1 \mathrm{Pt}-\mathrm{SiO}_{2}$ did not activate the surface hydroxyls to produce $\mathrm{CO}_{2}$ (water-gas shift reaction) until $195^{\circ} \mathrm{C}^{11}$. This highly reducible oxygen species may motivate initial $\mathrm{CO}$ oxidation $\left(\sim 50^{\circ} \mathrm{C}\right)$ through Mars-van Krevelen $(\mathrm{MvK})$ mechanism $^{47}$ and show a strong correlation between reaction rate and active oxygen amount in Fig. 6c. Therefore, the $\mathrm{Pt}-[\mathrm{O}]_{x}-\mathrm{Bi}$ structure with low valance state of $\mathrm{Pt}^{\delta+}(0<\delta<2)$ species in the used Bi-promoted samples provides superior active oxygen species to catalyze preliminary stage of $\mathrm{CO}$ oxidation.

The $\mathrm{CO}$ adsorption on $\mathrm{Pt}-[\mathrm{O}]_{x}-\mathrm{Bi}$ active site. Despite the identification of active site structure in silica-supported platinumbismuth catalysts being important, the adsorption of reaction gas is a more key factor for catalytic behavior. Because, recent reports have indicated that a lot of atomically dispersed platinum catalysts show low catalytic activity in $\mathrm{CO}$ oxidation due to over strong adsorption of $\mathrm{CO}$, even with maximized number density of reaction sites $27,28,32,48$. Therefore, it is significant to investigate the $\mathrm{CO}$ adsorption on active site for Bi-free and Bi-promoted catalysts. The in-situ DRIFTS experiments displayed that CO adsorption intensity of Bi-promoted sample is moderate compared to that of pure platinum sample (Fig. 7a), indicating the surface $\mathrm{Pt}-[\mathrm{O}]_{x}-\mathrm{Bi}$ structure could prevent oversaturated adsorption of $\mathrm{CO}$ molecule (CO poison) on Pt clusters or nanoparticles, just like the reported alkali-doped Pt catalysts ${ }^{11}$. The $\mathrm{CO}$ adsorption reached saturation rapidly for $1 \mathrm{Pt}-\mathrm{SiO}_{2}$ at $2062 \mathrm{~cm}^{-1}$ attributed to linear $\mathrm{CO}$ adsorbed on $\mathrm{Pt}^{0}$ sites $\left(\mathrm{Pt}^{0}-\mathrm{CO}\right)^{49}$ (Fig. $7 \mathrm{a}$ and Supplementary Fig. 17), resulting in no other $\mathrm{Pt}$ sites dissociating gases oxygen into active oxygen species ${ }^{19}$. However, the peak for $\mathrm{CO}$ adsorption over $1 \mathrm{Pt} 2 \mathrm{Bi}-\mathrm{SiO}_{2}$ was detected at $2043 \mathrm{~cm}^{-1}$, which was absolutely different linear $\mathrm{CO}$ adsorbed on $\mathrm{Pt}^{0}$ sites. This red-shift phenomenon can be eliminated the possibility of either size-effect of Pt species or CO adsorption on pure $\mathrm{Bi}$ species. In one hand, $1 \mathrm{Pt}-\mathrm{SiO}_{2}-400$ with total platinum cluster also showed the peak $\sim 2060 \mathrm{~cm}^{-1}$ (Supplementary Fig. 18) similar with the peak $\left(2062 \mathrm{~cm}^{-1}\right)$ in $1 \mathrm{Pt}-\mathrm{SiO}_{2}$. In another hand, there is no $\mathrm{CO}$ adsorption peak for $2 \mathrm{Bi}-\mathrm{SiO}_{2}$ except for gases $\mathrm{CO}$ peaks (Supplementary Fig. 19), no matter with oxidative or reduced pretreatment. Therefore, the low-frequency band at $2043 \mathrm{~cm}^{-1}$ is attributed to $\mathrm{CO}$ molecules adsorbed on the unique active site $\left(\mathrm{Pt}-[\mathrm{O}]_{x}-\mathrm{Bi}\right)$, even less doping of bismuth species (Supplementary Fig. 20), and this may result from the unique local coordination structure of $\mathrm{Pt}-[\mathrm{O}]_{x}-\mathrm{Bi}$ structure or electron transfer from platinum atom to $\mathrm{CO}$ molecule ${ }^{50,51}$. Panagiotopoulou and co-workers reported that the alkali additives to $\mathrm{Pt} / \mathrm{TiO}_{2}$ catalyst generate a low-frequency shoulder band $\left(\sim 2030 \mathrm{~cm}^{-1}\right)$ resulting in strengthen of $\mathrm{Pt}-\mathrm{CO}$ bond ${ }^{51}$. Furthermore, when the oxygen was introduced, the activated $\mathrm{CO}$ molecule adsorbed on $\mathrm{Pt}-[\mathrm{O}]_{x}-\mathrm{Bi}$ structure could be converted to $\mathrm{CO}_{2}$ quickly ( $\left.135 \mathrm{~s}\right)$ and completely (Fig. $\left.7 \mathrm{~b}\right)$. Our density functional theory (DFT) calculation builds up various simulation model for $\mathrm{Pt} @ \mathrm{PtO}_{x}$ without and with $\mathrm{Bi}$ dopant (Supplementary Fig. 21) and the corresponding calculated vibrational frequencies of a $\mathrm{CO}$ molecule adsorbed on different sites. The vibration peaks at $2062 \mathrm{~cm}^{-1}$ and $2043 \mathrm{~cm}^{-1}$ in the experiments were attributed to the configurations in Supplementary Figs. 21c, f respectively. One can see that upon the doping of the $\mathrm{Bi}$ atoms, the number of the Pt-O bonds had decreased. It is not surprising since $\mathrm{Bi}$ atoms are oxophilic and can seize O atoms from Pt. In Supplementary Fig. 22, we presented the density of states (DOS) for the $d$ electrons of the Pt atom (Supplementary Fig. 21c, f) on which the CO molecule adsorbs. As the coordination number of the Pt atom decreases, the center of the $d$ band becomes closer to the Fermi level, corresponding to strengthened activity. Thus, due to the unique structure of $\mathrm{Pt}-[\mathrm{O}]_{x}-\mathrm{Bi}$, more electron was transformed from $\mathrm{Pt}$ 
atom to $\mathrm{CO}$ molecules to activated carbon monoxide, resulting in the red-shift on $\mathrm{CO}$ adsorption band in DRIFTS experiments.

Additionally, we employed in-situ DRIFTS experiments with a mode: "CO adsorption $\rightarrow$ reaction conditions (1 vol.\% CO/20 vol.\% $\mathrm{O}_{2} / \mathrm{N}_{2}$ flow) at $200{ }^{\circ} \mathrm{C} \rightarrow \mathrm{CO}$ adsorption" to detect the stability of active site. For $1 \mathrm{Pt} 2 \mathrm{Bi}-\mathrm{SiO}_{2}$, the $\mathrm{Pt}-[\mathrm{O}]_{x}-\mathrm{Bi}$ structure could be maintained after CO oxidation $\left(2042 \mathrm{~cm}^{-1}\right)$, well consistent with the band after hydrogen pretreatment at $210^{\circ} \mathrm{C}$ (Fig. 7c). For $1 \mathrm{Pt}-$ $\mathrm{SiO}_{2}$, after $\mathrm{CO}$ oxidation, the $\mathrm{CO}$ adsorption band occurred a blue shift $\left(2072 \mathrm{~cm}^{-1}\right)$ compared to the band $\left(2062 \mathrm{~cm}^{-1}\right)$ after hydrogen reduction at $210^{\circ} \mathrm{C}$ (Supplementary Fig. 23), due to the surface oxidation of metallic Pt cluster.

\section{Discussion}

In summary, we have prepared silica-supported platinum-bismuth catalysts via an incipient wetness impregnation, possessing excellent sinter resistance due to the formation of oxidized $\mathrm{Pt}_{x} \mathrm{Bi}_{y} \mathrm{O}_{z}$ cluster. The Bi-promoted catalysts exhibit an absolutely different active site for platinum cluster with surface $\mathrm{Pt}-[\mathrm{O}]_{x}-\mathrm{Bi}$ structure compared with pure platinum sample, providing superior active oxygen species activated by $\mathrm{CO}$ at low temperature $\left(\sim 50^{\circ} \mathrm{C}\right)$ with a high $\mathrm{CO}_{2}$ production rate of $487 \mu \mathrm{mol}_{\mathrm{CO} 2}$ $\mathrm{g}_{\mathrm{Pt}}{ }^{-1} \mathrm{~s}^{-1}$ at $110^{\circ} \mathrm{C}$. Even after hydrogen reduction, the surface $\mathrm{Pt}-[\mathrm{O}]_{x}-\mathrm{Bi}$ structure still stabilizes platinum cluster in clusterscale with unique properties: (1) preventing oversaturated $\mathrm{CO}$ adsorption from poison of platinum species; (2) activating CO molecules to catalyze $\mathrm{CO}$ oxidation in a lower apparent activation energy. Therefore, we have provided a general approach towards design of potential active and stable platinum catalysts.

\section{Methods}

Catalyst preparation. $\mathrm{SiO}_{2}$ was calcination at $400^{\circ} \mathrm{C}$ for $4 \mathrm{~h}$ (ramping rate: $2{ }^{\circ} \mathrm{C} /$ $\mathrm{min}$ ) to remove surface water before catalysts preparation. Deposition of platinum, and bismuth onto the $\mathrm{SiO}_{2}$ support was carried out by a co-incipient wetness impregnation. Firstly, a solution of $\mathrm{Bi}\left(\mathrm{NO}_{3}\right)_{3}$ (50-124 mg respective) and $\mathrm{Pt}$ $\left(\mathrm{NH}_{3}\right)_{4}\left(\mathrm{NO}_{3}\right)_{2}(20 \mathrm{mg})$ in $0.1 \mathrm{~mol} / \mathrm{L} \mathrm{HNO}_{3}$ solutions $(3 \mathrm{~mL})$ was added dropwise onto $\mathrm{SiO}_{2}$ power $(1 \mathrm{~g})$ under manually stirring. The powders were standing in ambient conditions for $2 \mathrm{~h}$ and then dried in still air at $80^{\circ} \mathrm{C}$ for $12 \mathrm{~h}$, followed by air-calcination at $550^{\circ} \mathrm{C}$ for $4 \mathrm{~h}$ (ramping rate: $2^{\circ} \mathrm{C} / \mathrm{min}$ ). As comparison, we also prepared $1 \mathrm{Pt}-\mathrm{SiO}_{2}$ calcinated at $400^{\circ} \mathrm{C}, 1 \mathrm{Pt} 1 \mathrm{Bi}-\mathrm{SiO}_{2}$, and $2 \mathrm{Bi}-\mathrm{SiO}_{2}$ samples with same synthetic method. The $\mathrm{Bi}$ and $\mathrm{Pt}$ contents were controlled on demand during preparation process of catalysts, and the data of these catalysts is as follows:

$1 \mathrm{Pt}-\mathrm{SiO}_{2}$ (1 wt. \% Pt, 0 wt. \% $\mathrm{Bi}$ ),

$1 \mathrm{Pt} 2 \mathrm{Bi}-\mathrm{SiO}_{2}$ (1 wt. \% Pt, 2 wt. \% Bi),

$1 \mathrm{Pt} 5 \mathrm{Bi}-\mathrm{SiO}_{2}$ (1 wt. \% Pt, 5 wt. \% Bi)

$2 \mathrm{Bi}-\mathrm{SiO}_{2}(2$ wt. \% $\mathrm{Bi})$

$1 \mathrm{Pt}-\mathrm{SiO}_{2}-400$ (1 wt. \% Pt)

$1 \mathrm{Pt} 1 \mathrm{Bi}-\mathrm{SiO}_{2}$ (1 wt. \% Pt, 1 wt. \% Bi).

Catalytic activity tests. The $\mathrm{CO}$ oxidation activities for the $\mathrm{PtBi}-\mathrm{SiO}_{2}$ samples were evaluated in a plug flow reactor using $30 \mathrm{mg}$ of sieved $(20-40 \mathrm{mesh})$ powders in a gas mixture of 1 vol.\% $\mathrm{CO} / 20 \mathrm{vol} . \% \mathrm{O}_{2} / \mathrm{N}_{2}$ (from Jinan Deyang Corporation, $99.997 \%$ purity) at a flow rate of $67 \mathrm{~mL} / \mathrm{min}$ giving a gas hourly space velocity (GHSV) of $\sim 134,000 \mathrm{~mL} \mathrm{~g}_{\mathrm{cat}}{ }^{-1} \mathrm{~h}^{-1}$. The catalysts were pretreated in $5 \% \mathrm{H}_{2} / \mathrm{N}_{2}$ (50 $\mathrm{mL} / \mathrm{min}$ ) at $210^{\circ} \mathrm{C}$ for $30 \mathrm{~min}$ before reaction with $10^{\circ} \mathrm{C} \mathrm{min}-1$. After the catalysts cooled down to room temperature under a flow of pure $\mathrm{N}_{2}$ gas, reactant gases were passed through the reactor. The outlet gas compositions of $\mathrm{CO}$ and $\mathrm{CO}_{2}$ were monitored online by nondispersive IR spectroscopy (Gasboard 3500, Wuhan Sifang Company, China). CO conversion was defined as $\mathrm{CO}_{\text {reaction }} / \mathrm{CO}_{\text {input }} \times 100 \%$. The related stability tests were done in the same conditions at the constant reaction temperature of $100{ }^{\circ} \mathrm{C}$ for $10 \mathrm{~h}$ with a GHSV of $\sim 134,000 \mathrm{~mL} \mathrm{~g}_{\text {cat }}{ }^{-1} \mathrm{~h}^{-1}$. Rate measurements were made in the separate catalytic tests rather than the "light-off" mode, i.e., the same gas composition, but at specific space velocities to ensure operation in the kinetic regime $(<20 \%$ conversion of CO).

Materials characterization. The actual platinum and bismuth concentrations of the catalysts were analyzed by inductively coupled plasma atomic emission spectroscopy (ICP-AES; Optima 5300DV, PerkinElmer). The air-calcined samples (fresh catalysts) were used directly for characterization. First, $0.1 \mathrm{~g}$ catalyst (accurate to $0.0001 \mathrm{~g}$ ) was added to $2 \mathrm{~mL}$ hydrofluoric acid under continuous stirring until the powder was dissolved adequately. Second, the as-formed $\mathrm{SiF}_{4}$ was removed via evaporation. Then, almost $3 \mathrm{~mL}$ of nitric acid was introduced and the solution was kept slightly boiling for $2 \mathrm{~h}$. Finally, the solution was cooled to nearly $25^{\circ} \mathrm{C}$ and diluted for the ICP-AES test.

XRD patterns were recorded on a Bruker D8 Advance diffractometer $(40 \mathrm{kV}$, $40 \mathrm{~mA}$ ) with a scanning rate of $4^{\circ} \mathrm{min}^{-1}$, using $\mathrm{Cu} K_{\alpha 1}$ radiation $(\lambda=1.5406 \AA)$. The diffraction patterns were collected from 10 to $80^{\circ}$ with a step of $0.02^{\circ}$. The $2 \theta$ angles were calibrated with a $\mu \mathrm{m}$-scale Alumina disc. The powder sample after grinding was placed inside a quartz sample holder for each test. XPS analysis was performed on an Axis Ultra XPS spectrometer (Kratos, U.K.) with $225 \mathrm{~W}$ of $\mathrm{Al} \mathrm{Ka}$ radiation. The $\mathrm{C} 1 \mathrm{~s}$ line at $284.8 \mathrm{eV}$ was used to calibrate the binding energies.

The nitrogen adsorption-desorption measurements were performed on an ASAP 2020-HD88 analyzer (Micromeritics Co. Ltd.) at $77 \mathrm{~K}$. The measured powders were degassed at $250^{\circ} \mathrm{C}$ under vacuum $(<100 \mu \mathrm{mHg})$ for over $4 \mathrm{~h}$. The BET specific surface areas $\left(S_{\mathrm{BET}}\right)$ were calculated from data in the relative pressure range between 0.05 and 0.20 . The pore diameter $\left(D_{\mathrm{p}}\right)$ distribution was calculated from the adsorption branch of the isotherms, based on the BJH method.

The TEM and high-resolution TEM (HRTEM) experiments were carried out on a FEI Tecnai $G^{2}$ F20 microscope operating at $200 \mathrm{kV}$. All the tested samples were suspended in ethanol, and then a drop of this dispersed suspension was placed on an ultra-thin (3-5 $\mathrm{nm}$ in thickness) carbon film-coated $\mathrm{Cu}$ grid. The as-formed sample grid was dried naturally under ambient conditions before loaded into the TEM sample holder. The aberration-corrected HAADF-STEM images were carried out on a JEOL ARM200F microscope equipped with probe-forming sphericalaberration corrector.

XAFS experiments. $\mathrm{Pt}_{3}\left(E_{0}=11564.0 \mathrm{eV}\right)$ and $\mathrm{Bi}_{3}\left(E_{0}=13419.0 \mathrm{eV}\right)$ edge was performed at BL14W1 beamline of Shanghai Synchrotron Radiation Facility (SSRF) operated at $3.5 \mathrm{GeV}$ under "top-up" mode with a constant current of 260 $\mathrm{mA}$. The XAFS data were recorded under fluorescence mode with a Lytle detector for $\mathrm{Pt} / \mathrm{PtBi}-\mathrm{SiO}_{2}$ samples. Only X-ray absorption near-edge structure (XANES) data of $\mathrm{Bi} \mathrm{L}_{3}$ edge was collected due to the similar edge energies of $\mathrm{Bi}$ and $\mathrm{Pt} \mathrm{L}_{3}$ edge. The energy was calibrated accordingly to the absorption edge of pure $\mathrm{Pt}$ and Bi foil. Athena and Artemis codes were used to extract the data and fit the profiles. For the XANES part, the experimental absorption coefficients as function of energies $\mu(E)$ were processed by background subtraction and normalization procedures. Based on the normalized XANES profiles, the molar fraction of $\mathrm{Pt}^{4+} / \mathrm{Pt}^{0}$ and $\mathrm{Bi}^{3+} / \mathrm{Bi}^{0}$ can be determined by the linear combination fit with the help of various references ( $\mathrm{Pt}$ foil for $\mathrm{Pt}^{0}, \mathrm{PtO}_{2}$ for $\mathrm{Pt}^{4+}, \mathrm{Bi}$ foil for $\mathrm{Bi}^{0}$ and $\mathrm{Bi}_{2} \mathrm{O}_{3}$ for $\mathrm{Bi}^{3+}$ ). For the extended X-ray absorption fine structure (EXAFS) part, the Fourier transformed (FT) data in $R$ space were analyzed by applying $\mathrm{PtO}_{2}$ and metallic $\mathrm{Pt}$ model for $\mathrm{Pt}-\mathrm{O}$ and $\mathrm{Pt}-\mathrm{Pt}$ contributions. The passive electron factors, $\mathrm{S}_{0}{ }^{2}$, were determined by fitting the experimental data on $\mathrm{Pt}$ and $\mathrm{Bi}$ foils, and fixing the coordination number $(C N)$ of $\mathrm{Pt}-\mathrm{Pt}$ and $\mathrm{Bi}-\mathrm{Bi}$ to be 12 , and then fixed for further analysis of the measured samples. The parameters describing the electronic properties (e.g., correction to the photoelectron energy origin, $E_{0}$ ) and local structure environment including coordination number $(C N)$, bond distance $(R)$ and Debye-Waller factor around the absorbing atoms were allowed to vary during the fit process. To distinguish the effect of Debye-Waller factor from coordination number, we set $\sigma^{2}$ to be 0.0030 and $0.0080 \AA^{2}$ for all the analyzed $\mathrm{Pt}-\mathrm{O}$ and $\mathrm{Pt}-\mathrm{Pt}$ shells, according to the fitted results of $\mathrm{Pt}$ foil and $\mathrm{PtO}_{2}$ standards. We also set $\sigma^{2}$ to be $0.008 \AA^{2}$ for all the analyzed $\mathrm{Pt}-\mathrm{Bi}$ paths, considering that the $Z$ number of $\mathrm{Bi}$ (83) is close to that of $\mathrm{Pt}(78)$. To distinguish the effect of correction to the photoelectron energy origin from distance, we set $\Delta E_{0}$ to be $11.3,13.3$, and $14.1 \mathrm{eV}$ for fresh $1 \mathrm{Pt}-\mathrm{SiO}_{2}, 1 \mathrm{Pt} 2 \mathrm{Bi}-\mathrm{SiO}_{2}$, and $1 \mathrm{Pt} 5 \mathrm{Bi}-\mathrm{SiO}_{2}$, respectively, which were obtained from the linear combination fits on XANES profiles and the fitting results of Pt foil $\left(\Delta E_{0}=8.3 \pm 1.2 \mathrm{eV}\right)$ and bulk $\mathrm{PtO}_{2}\left(\Delta E_{0}=15.0 \pm 0.9 \mathrm{eV}\right)$ standards and the $\Delta E_{0}$ for all used samples is $7.4 \pm 1.8 \mathrm{eV}$ according to EXAFS fitting results. For quasi in-situ XAFS experiment, the samples were pretreated in a stainless reactor with two globe valves and transferred to a glove box under nitrogen atmosphere and ambient temperature for tabletting without exposure to air.

In-situ DRIFTS. It was carried out in a diffuse reflectance cell (Harrick system) equipped with $\mathrm{CaF}_{2}$ windows on a Bruker Vertex 70 spectrometer using a mercurycadmium-telluride (MCT) detector cooled with liquid nitrogen. In a typical steady test, the powder sample (ca. $20 \mathrm{mg}$ ) was pretreated in air $\left(21 \mathrm{vol} \% \mathrm{O}_{2} / 79 \mathrm{vol} \% \mathrm{~N}_{2}\right)$ at $300{ }^{\circ} \mathrm{C}$ or in hydrogen gas $\left(5\right.$ vol. $\left.\% \mathrm{H}_{2} / \mathrm{He}\right)$ at $210^{\circ} \mathrm{C}$ for $30 \mathrm{~min}$ and cooled to room temperature under pretreatment atmosphere $\left(30 \mathrm{~mL} \mathrm{~min}^{-1}\right)$. Then a background spectrum was collected via $32 \mathrm{scans}$ at $4 \mathrm{~cm}^{-1}$ resolution. The reaction gas with $1 \% \mathrm{CO} / 20 \% \mathrm{O}_{2} / 79 \% \mathrm{~N}_{2}$ was introduced into the in-situ chamber $(30 \mathrm{~mL} \mathrm{~min}$ ${ }^{-1}$ ) and heated in a stepped way (every $40 \mathrm{~K}$ ); DRIFTS spectra were obtained by subtracting the background spectrum from subsequent spectra. The IR spectra for every step were recorded continuously for $40 \mathrm{~min}$ to reach the equilibrium. Analysis of the spectra has been carried out by using OPUS software. For further investigation of the process of adsorption-desorption of $\mathrm{CO}$ over $\mathrm{Pt} / \mathrm{PtBi}-\mathrm{SiO}_{2}$ catalysts, a " $\mathrm{CO}-\mathrm{N}_{2}-\mathrm{CO}-\mathrm{O}_{2}$ " test was measured with in situ DRIFTS. The process of activation was carried out as described above. Then a background spectrum was collected at a certain temperature $\left(100^{\circ} \mathrm{C}\right)$ under pure $\mathrm{N}_{2}(30 \mathrm{~mL}$ $\min ^{-1}$ ). The catalyst was exposed continuously to $2 \% \mathrm{CO}$ in $\mathrm{N}_{2}$ for $\mathrm{CO}$ adsorption for $30 \mathrm{~min}$. Once $\mathrm{CO}$ gas was switched to an $\mathrm{N}_{2}$ stream, also the corresponding IR spectra were recorded for $30 \mathrm{~min}$. Then the catalyst was exposed to $2 \% \mathrm{CO}$ in $\mathrm{N}_{2}$ for CO re-adsorption for $30 \mathrm{~min}$; ultimately $1 \% \mathrm{O}_{2}$ in an $\mathrm{N}_{2}$ stream was introduced, 
in order to follow the surface changes during the $\mathrm{CO}$ removal process. The $\mathrm{CO}$ adsorption for $\mathrm{Pt} / \mathrm{PtBi}-\mathrm{SiO}_{2}$ samples was also carried out in the mode " $\mathrm{CO}$ adsorption $\rightarrow \mathrm{CO}$ oxidation at $200^{\circ} \mathrm{C} \rightarrow \mathrm{CO}$ adsorption" to detect structure evolution of adsorption site after $\mathrm{CO}$ oxidation.

DFT calculations. First-principles calculations were performed within the framework of the density functional theory (DFT) using the Vienna ab initio simulation package (VASP) ${ }^{52,53}$. The projector augmented wave (PAW) method was employed ${ }^{54}$, and the wave functions were expanded by plane-wave basis sets with an energy cutoff of $400 \mathrm{eV}$. The exchange-correlation effects were described by the optPBE-vdW functional ${ }^{55,56}$, which explicitly takes Van der Waals interactions into account. The simulation model of the $\mathrm{PtO}_{x}$ system was constructed by nesting an icosahedral $\mathrm{Pt}_{55}$ cluster inside a platinum oxide layer that contains $32 \mathrm{Pt}$ atoms and $66 \mathrm{O}$ atoms, and the deposited $\mathrm{Bi}$ atoms (10 atoms in the model) were placed on the outer layer of the platinum oxide. The unit cell contains enough vacuum along all three directions to eliminate spurious interactions between periodic images. Since the model of the system is an isolated cluster, the first Brillouin zone was sampled using the $\Gamma$ point only. In the geometry optimizations, all atoms were allowed to relax until the maximum force was below $0.03 \AA / e V$. The vibrational frequencies of $\mathrm{CO}$ were calculated through a finite differential approach, in which only the $\mathrm{CO}$ adsorbate, the $\mathrm{Pt}$ atom that connects it, and the surrounding $\mathrm{Pt}, \mathrm{O}$ and $\mathrm{Bi}$ atoms were allowed to move while all other atoms were kept frozen.

Reducible property and surface oxygen. Hydrogen temperature-programmed reduction $\left(\mathrm{H}_{2}-\mathrm{TPR}\right)$ was applied to determine the pretreatment temperature under hydrogen and reducibility. The measurements were carried out on a Micromeritics Autochem II 2920 instrument. Fresh (as calcinated in air) catalysts were used for characterization. Prior to the measurement, the catalyst (20-40 mesh, $\sim 100 \mathrm{mg}$ ) was pretreated for $30 \mathrm{~min}$ in a flow of $5 \% \mathrm{O}_{2} / \mathrm{He}\left(30 \mathrm{~mL} \mathrm{~min}^{-1}\right)$ at $300^{\circ} \mathrm{C}\left(10^{\circ} \mathrm{C} \mathrm{min}-1\right)$. The test was carried out from room temperature to $600{ }^{\circ} \mathrm{C}$ $\left(10^{\circ} \mathrm{C} \mathrm{min}-1\right)$ at a ramp of $10{ }^{\circ} \mathrm{C} \mathrm{min}-1$ under $5 \% \mathrm{H}_{2} / \mathrm{He}\left(30 \mathrm{~mL} \mathrm{~min}^{-1}\right)$. A thermal conductivity detector (TCD) was used to detect the changes of hydrogen concentration. The in situ $\mathrm{H}_{2}$-TPR for used samples was also performed on Autochem II 2920 instrument after CO oxidation without air exposure with $\mathrm{He}$ purging to remove reactant gas completely.

Carbon monoxide Temperature-programmed reduction (CO-TPR) experiments using $\mathrm{CO}$ as reductant were performed on Micromeritics Autochem II 2920 instrument with mass spectrometer (Tilon GRP Technology Limited LCD200M) to detect the active oxygen species in fresh and used samples. The fresh sample $(100 \mathrm{mg}, 20-40 \mathrm{mesh})$ was pretreated in $5 \% \mathrm{O}_{2} / \mathrm{He}\left(30 \mathrm{~mL} \mathrm{~min}^{-1}\right)$ at $300{ }^{\circ} \mathrm{C}$ $\left(10^{\circ} \mathrm{C} \mathrm{min}^{-1}\right)$ for $30 \mathrm{~min}$. The used samples after CO completely conversion was conducted for CO-TPR without air exposure and then cooling down to $30^{\circ} \mathrm{C}$ and switching to $\mathrm{He}\left(50 \mathrm{~mL} \mathrm{~min}^{-1}\right)$ for $10 \mathrm{~min}$ to remove reactant gas $\left(\mathrm{CO}\right.$ and $\mathrm{O}_{2}$ molecules). Finally, the sample was heated from room temperature to $500^{\circ} \mathrm{C}$ with a step of $5^{\circ} \mathrm{C} \mathrm{min}^{-1}$ under a mixture gas flow of $5 \% \mathrm{CO} / \mathrm{He}\left(20 \mathrm{~mL} \mathrm{~min}^{-1}\right)$. During the measurement, the signals of $\mathrm{He}(m / z=4), \mathrm{CO}_{2}(m / z=44), \mathrm{H}_{2} \mathrm{O}(\mathrm{m} / z=18,17)$, $\mathrm{CO}(\mathrm{m} / z=28,16)$, and $\mathrm{H}_{2}(\mathrm{~m} / z=2)$ were detected. The reported $\mathrm{CO}_{2}$ and $\mathrm{H}_{2}$ data were normalized by dividing by the corresponding He standard signal $(\mathrm{m} / z=4)$.

\section{Data availability}

The authors declare that all other data supporting the findings of this study are available within the article and Supplementary information files, and also are available from the corresponding author on reasonable request.

Received: 7 December 2020; Accepted: 23 April 2021; Published online: 07 June 2021

\section{References}

1. Liu, W. \& Flytzani-Stephanopoulos, M. Total oxidation of carbon monoxide and methane over transition metal-fluorite oxide composite catalysts I. Catalyst composition and activity. J. Catal. 153, 304-316 (1995).

2. Nie, L. et al. Activation of surface lattice oxygen in single-atom $\mathrm{Pt} / \mathrm{CeO}_{2}$ for low-temperature CO oxidation. Science 358, 1419-1423 (2017).

3. Qiao, B. T. et al. Single-atom catalysis of $\mathrm{CO}$ oxidation using $\mathrm{Pt}_{1} / \mathrm{FeO}_{x}$. Nat. Chem. 3, 634-641 (2011).

4. An, K. et al. Enhanced $\mathrm{CO}$ oxidation rates at the interface of mesoporous oxides and Pt nanoparticles. J. Am. Chem. Soc. 135, 16689-16696 (2013).

5. Michalak, W. D. et al. CO oxidation on PtSn nanoparticle catalysts occurs at the interface of $\mathrm{Pt}$ and $\mathrm{Sn}$ oxide domains formed under reaction conditions. J. Catal. 312, 17-25 (2014).

6. Nan, B. et al. Effects of multiple platinum species on catalytic reactivity distinguished by electron microscopy and x-ray absorption spectroscopy techniques. J. Phys. Chem. C 121, 25805-25817 (2017).

7. Deelen, T. W., Mejía, C. H. \& Jong, K. P. Control of metal-support interactions in heterogeneous catalysts to enhance activity and selectivity. Nat. Catal. 2, 955-970 (2019).
8. Acerbi, N., Tsang, S. C. E., Jones, G., Golunski, S. \& Collier, P. Rationalization of interactions in precious metal/ceria catalysts using the d-band center model. Angew. Chem. Int. Ed. 52, 7737-7741 (2013).

9. Almana, N. et al. Design of a core-shell $\mathrm{Pt}-\mathrm{SiO}_{2}$ catalyst in a reverse microemulsion system: distinctive kinetics on $\mathrm{CO}$ oxidation at low temperature. J. Catal. 340, 368-375 (2016).

10. Haneda, M., Watanabe, T., Kamiuchi, N. \& Ozawa, M. Effect of platinum dispersion on the catalytic activity of $\mathrm{Pt} / \mathrm{Al}_{2} \mathrm{O}_{3}$ for the oxidation of carbon monoxide and propene. Appl. Catal. B 142-143, 8-14 (2013).

11. Zhai, Y. P. et al. Alkali-stabilized $\mathrm{Pt}-\mathrm{OH}_{x}$ species catalyze low-temperature water-gas shift reactions. Science 329, 1633-1636 (2010).

12. Xu, H., Fu, Q., Guo, X. G. \& Bao, X. H. Architecture of Pt-Co bimetallic catalysts for catalytic CO oxidation. ChemCatChem 4, 1645-1652 (2012).

13. Lou, Y. et al. The effects of $\mathrm{Bi}_{2} \mathrm{O}_{3}$ on the $\mathrm{CO}$ oxidation over $\mathrm{Co}_{3} \mathrm{O}_{4}$. Catal. Today 175, 610-614 (2011).

14. Ma, D.-D. et al. Promoting effect of bismuth oxide on Pd for low temperature CO oxidation. ChemCatChem 9, 499-504 (2017).

15. Mondelli, C., Grunwaldt, J.-D., Ferric, D. \& Baiker, A. Role of Bi promotion and solvent in platinum-catalyzed alcohol oxidation probed by in situ X-ray absorption and ATR-IR spectroscopy. Phys. Chem. Chem. Phys. 12, 5307-5316 (2010).

16. Figueiredo, M. C. et al. Direct alcohol fuel cells: Increasing platinum performance by modification with sp-group metals. J. Power Sources 275, 341-350 (2015)

17. Feng, S. X. et al. Experimental and theoretical investigation of the role of bismuth in promoting the selective oxidation of glycerol over supported Pt-Bi catalyst under mild conditions. ACS Catal. 10, 6071-6083 (2020).

18. Xiao, Y. \& Varma, A. Highly selective nonoxidative coupling of methane over Pt-Bi bimetallic catalysts. ACS Catal. 8, 2735-2740 (2018).

19. Ding, K. L. et al. Identification of active sites in $\mathrm{CO}$ oxidation and water-gas shift over supported Pt catalysts. Science 350, 189-192 (2015).

20. Shang, Z. et al. Activity and stability of $\mathrm{Co}_{3} \mathrm{O}_{4}$-based catalysts for soot oxidation: The enhanced effect of $\mathrm{Bi}_{2} \mathrm{O}_{3}$ on activation and transfer of oxygen. Appl. Catal. B 209, 33-44 (2017).

21. Wang, W.-W. et al. Crystal plane effect of ceria on supported copper oxide cluster catalyst for $\mathrm{CO}$ oxidation: importance of metal-support interaction. ACS Catal. 7, 1313-1329 (2017).

22. Du, P.-P. et al. Effect of strongly bound copper species in copper-ceria catalyst for preferential oxidation of carbon monoxide. Appl. Catal. A 518, 87-101 (2016).

23. $\mathrm{Zhu}, \mathrm{H}$. Y. et al. Constructing hierarchical interfaces: $\mathrm{TiO}_{2}$-supported PtFe$\mathrm{FeO}_{x}$ nanowires for room temperature $\mathrm{CO}$ oxidation. J. Am. Chem. Soc. 137, 10156-10159 (2015).

24. Weng, Z. et al. Metal/oxide interface nanostructures generated by surface segregation for electrocatalysis. Nano Lett. 15, 7704-7710 (2015).

25. Peng, L. S. et al. Chimney effect of the interface in metal oxide/metal composite catalysts on the hydrogen evolution reaction. Appl. Catal. B 245, 122-129 (2019).

26. Chen, G. X. et al. Interfacial effects in iron-nickel hydroxide-platinum nanoparticles enhance catalytic oxidation. Science 344, 495-499 (2014).

27. Yoo, M. et al. A tailored oxide interface creates dense Pt single-atom catalysts with high catalytic activity. Energy Environ. Sci. 13, 1231-1239 (2020).

28. DeRita, L. et al. Structural evolution of atomically dispersed Pt catalysts dictates reactivity. Nat. Mater. 18, 746-751 (2019).

29. Xie, J. H. et al. Influence of dioxygen on the promotional effect of Bi during Pt-catalyzed oxidation of 1,6-Hexanediol. ACS Catal. 6, 4206-4217 (2016).

30. Binder, A. J., Toops, T. J., Unocic, R. R., Parks, J. E. \& Dai, S. Low-temperature $\mathrm{CO}$ oxidation over a ternary oxide catalyst with high resistance to hydrocarbon inhibition. Angew. Chem. Int. Ed. 54, 13263-13267 (2015).

31. Jeong, H. et al. Controlling the oxidation state of Pt single atoms for maximizing catalytic activity. Angew. Chem. Int. Ed. 59, 20691-20696 (2020).

32. Jones, J. et al. Thermally stable single-atom platinum-on-ceria catalysts via atom trapping. Science 353, 150-154 (2016).

33. Zhang, $\mathrm{Z}$. L. et al. Thermally stable single atom $\mathrm{Pt} / \mathrm{m}-\mathrm{Al}_{2} \mathrm{O}_{3}$ for selective hydrogenation and CO oxidation. Nat. Commun. 8, 16100 (2017).

34. Mahmudov, R., Shu, Y. Y., Rykov, S., Chen, J. G. \& Huang, C. P. The reduction of perchlorate by hydrogenation catalysts. Appl. Catal. B 81, 78-87 (2008).

35. Wu, C. H. et al. Bimetallic synergy in cobalt-palladium nanocatalysts for $\mathrm{CO}$ oxidation. Nat. Catal. 2, 78-85 (2019).

36. Lee, H. et al. Boosting hot electron flux and catalytic activity at metal-oxide interfaces of PtCo bimetallic nanoparticles. Nat. Commun. 9, 2235 (2018).

37. Kim, T.-S. et al. Catalytic synergy on PtNi bimetal catalysts driven by interfacial intermediate structures. ACS Catal. 10, 10459-10467 (2020).

38. $\mathrm{Xu}$, $\mathrm{Y}$. et al. Highly selective olefin production from $\mathrm{CO}_{2}$ hydrogenation on iron catalysts: a subtle synergy between manganese and sodium additives. Angew. Chem. Int. Ed. 59, 21736-21744 (2020).

39. Ke, J. et al. Strong local coordination structure effects on subnanometer $\mathrm{PtO}_{x}$ clusters over $\mathrm{CeO}_{2}$ nanowires probed by low-temperature $\mathrm{CO}$ oxidation. ACS Catal. 5, 5164-5173 (2015). 
40. Uner, D., Tapan, N. A., Özen, I. \& Üner, M. Oxygen adsorption on $\mathrm{Pt} / \mathrm{TiO}_{2}$ catalysts. Appl. Catal. A 251, 225-234 (2003).

41. Frenkel, A. I., Hills, C. W. \& Nuzzo, R. G. A view from the inside: complexity in the atomic scale ordering of supported metal nanoparticles. J. Phys. Chem. $B$ 105, 12690-12703 (2001).

42. Choi, J., Zhang, S. H. \& Hill, J. M. Reducibility and toluenehydrogenation activity of nickel catalysts supported on $\gamma-\mathrm{Al}_{2} \mathrm{O}_{3}$ and $\mathrm{\kappa}-\mathrm{Al}_{2} \mathrm{O}_{3}$. Catal. Sci. Technol. 2, 179-186 (2012).

43. Zedan, A. F., Mohamed, A. T., El-Shall, M. S., AlQaradawi, S. Y. \& AlJaber, A. $\mathrm{S}$. Tailoring the reducibility and catalytic activity of $\mathrm{CuO}$ nanoparticles for low temperature CO oxidation. RSC Adv. 8, 19499-19511 (2018).

44. Lei, Q. et al. Influence of cerium precursors on the structure and reducibility of mesoporous $\mathrm{CuO}-\mathrm{CeO}_{2}$ catalysts for $\mathrm{CO}$ oxidation. Appl. Catal. B 119-120, 308-320 (2012).

45. Zhu, S. H. et al. $\mathrm{SiO}_{2}$ promoted $\mathrm{Pt} / \mathrm{WO}_{x} / \mathrm{ZrO}_{2}$ catalysts for the selective hydrogenolysis of glycerol to 1,3-propanediol. Appl. Catal. B 158, 391-399 (2014).

46. Lan, M. L. et al. Chemoselective hydrogenation of 3-nitrostyrene to 3aminostyrene over Pt-Bi/ $\mathrm{TiO}_{2}$ catalysts. Mol. Catal. 432, 23-30 (2017),

47. Wang, C. L. et al. Water-mediated Mars-Van Krevelen mechanism for CO oxidation on ceria-supported single-atom $\mathrm{Pt}_{1}$ catalyst. ACS Catal. 7, 887-891 (2017).

48. Kunwar, D. et al. Stabilizing high metal loadings of thermally stable platinum single atoms on an industrial catalyst support. ACS Catal. 9, 3978-3990 (2019).

49. Brieger, C. et al. A combined in-situ XAS-DRIFTS study unraveling adsorbate induced changes on the Pt nanoparticle structure. J. Catal. 339, 57-67 (2016).

50. Liu, A. N. et al. Getting insights into the temperature-specific active sites on platinum nanoparticles for $\mathrm{CO}$ oxidation: a combined in situ spectroscopic and ab initio density functional theory study. ACS Catal. 9, 7759-7768 (2019).

51. Panagiotopoulou, P. \& Kondarides, D. I. Effects of alkali additives on the physicochemical characteristics and chemisorptive properties of $\mathrm{Pt} / \mathrm{TiO}_{2}$ catalysts. J. Catal. 260, 141-149 (2008).

52. Kresse, G. \& Furthmüller, J. Efficiency of ab-initio total energy calculations for metals and semiconductors using a plane-wave basis set. Comput. Mater. Sci. 6, 15-50 (1996).

53. Kresse, G. \& Furthmüller, J. Efficient iterative schemes for ab initio totalenergy calculations using a plane-wave basis set. Phys. Rev. B 54, 11169-11186 (1996).

54. Blöchl, P. E. Projector augmented-wave method. Phys. Rev. B 50, 17953-17979 (1994).

55. Dion, M., Rydberg, H., Schröder, E., Langreth, D. C. \& Lundqvist, B. I. Van der Waals density functional for general geometries. Phys. Rev. Lett. 92 , 246401 (2004).

56. Klimeš, J., Bowler, D. R. \& Michaelides, A. Chemical accuracy for the van der Waals density functional. J. Phys. Condens. Matter 22, 022201 (2010).

57. Moses-DeBusk, M. et al. CO oxidation on supported single Pt atoms: experimental and $\mathrm{ab}$ initio density functional studies of $\mathrm{CO}$ interaction with $\mathrm{Pt}$ atom on $\theta-\mathrm{Al}_{2} \mathrm{O}_{3}(010)$ surface. J. Am. Chem. Soc. 135, 12634-12645 (2013).

58. Zhou, Y. et al. Photothermal catalysis over nonplasmonic $\mathrm{Pt} / \mathrm{TiO}_{2}$ studied by operando HERFD-XANES, resonant XES, and DRIFTS. ACS Catal. 8, 11398-11406 (2018).

59. Pereira-Hernández, X. I. et al. Tuning $\mathrm{Pt}-\mathrm{CeO}_{2}$ interactions by hightemperature vapor-phase synthesis for improved reducibility of lattice oxygen. Nat. Commun. 10, 1358 (2019).

\section{Acknowledgements}

This work was supported by "National Key Basic Research Program of China" (2017YFA0403402); "Project of the National Natural Science Foundation of China" (21773288, U1932119, 21771117 and 21805167), the Taishan Scholar Project of Shandong Province of China, the Young Scholars Program of Shandong University and the Outstanding Youth Scientist Foundation of Hunan Province (2020JJ2001). This work was also supported by shanghai large Scientific facilities center (Y92G021221). We thank Dr. Shuang-quan Hu (Evonik Industries) for his kind help on supply of high surface-area silica support.

\section{Author contributions}

B.N. developed platinum-bismuth catalysts, tested for catalytic activity, and prepared the article. M.S. carried out the TEM/HRTEM images for all catalysts. Q.F. and J.Y.L. made the DFT calculations. J.Y. finished partial characterization of catalysts. L.L.Z. and W.W.W. measured in-situ DRIFTS data. L.N.L. carried out XAS measurements and analyzed the data. C.M. carried out the aberration-correction HAADF-STEM and EDS mapping images of all catalysts. J.X.C. performed the CO-TPR experiments. R.S. and C.J.J. conceived and supervised the project, procured funds, and wrote the manuscript, with contributions from all authors.

\section{Competing interests}

The authors declare no competing interests.

\section{Additional information}

Supplementary information The online version contains supplementary material available at https://doi.org/10.1038/s41467-021-23696-7.

Correspondence and requests for materials should be addressed to C.-J.J., C.M. or R.S

Peer review information Nature Communications thanks Hyun You Kim and the other, anonymous, reviewers for their contribution to the peer review of this work. Peer reviewer reports are available.

Reprints and permission information is available at http://www.nature.com/reprints

Publisher's note Springer Nature remains neutral with regard to jurisdictional claims in published maps and institutional affiliations.

Open Access This article is licensed under a Creative Commons Attribution 4.0 International License, which permits use, sharing, adaptation, distribution and reproduction in any medium or format, as long as you give appropriate credit to the original author(s) and the source, provide a link to the Creative Commons license, and indicate if changes were made. The images or other third party material in this article are included in the article's Creative Commons license, unless indicated otherwise in a credit line to the material. If material is not included in the article's Creative Commons license and your intended use is not permitted by statutory regulation or exceeds the permitted use, you will need to obtain permission directly from the copyright holder. To view a copy of this license, visit http://creativecommons.org/ licenses/by/4.0/

(C) The Author(s) 2021 